\title{
Die inkarnering van die missio Dei as praktykmodel vir die Nederduitsch Hervormde Kerk van Afrika
}

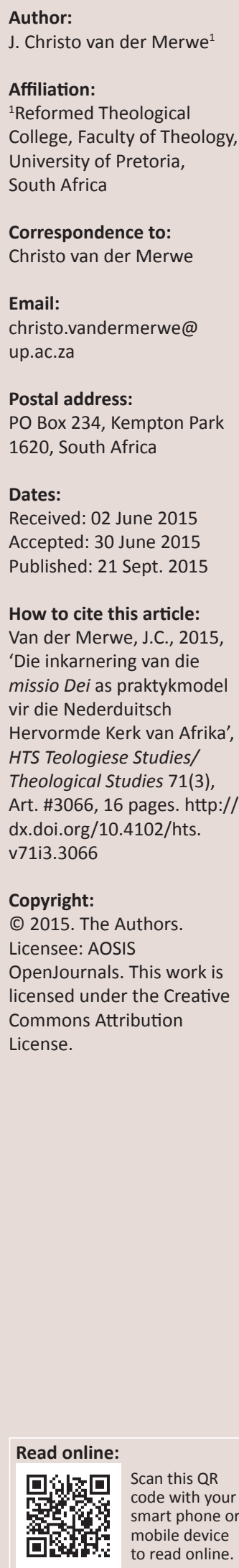

The incarnation of the missio Dei practice model for the Dutch Reformed Church of Africa. The decline of the church in the West is of great concern to many today. The Netherdutch Reformed Church of Africa (NRCA), experiences the same tendency. We are living in a time when survival is on the mind of most mainline congregations and denominations. The question is what shall we do to turn this situation around? The answer is to be found in the rediscovery of what it means for the church to be missional. The knowledge about how the early church functioned helps us to rediscover the character of early Christian mission, much of what is drawn together in the concept of incarnational mission. This article examines incarnational mission as the understanding and practise of Christian witness that is rooted in and shaped by the life, ministry, suffering, death and resurrection of Jesus. Understanding mission incarnationally in this manner is an integrative way to approach the church's missionary vocation and to avoid the typical Western reduction of mission to one of the many programms of the church. The article, by exploring the meaning of incarnational mission, endeavours to be both constructive with regard to the biblical and theological understanding of the message, and polemical with regard to the context and history of mission, especially in the Western tradition. This article follows Darrell Guder in arguing that the historical 'happenedness' of Jesus' life both enables and defines Christian witness. In exploring the missional significance of the incarnation, the article tries to avoid any dilution of the centrality of the incarnation event.

\section{Inleiding}

Die oorlewingsmoontlikheid van die tradisioneel reformatoriese kerke word wêreldwyd bevraagteken. Sommige voorspel selfs hierdie kerke se onvermydelike verdwyning (Peterson 2013:1). 'n Goeie voorbeeld is die somber prent wat Malphurs reeds in 1993 van die kerk in die VSA geteken het:

Not only are United States churches plateaued and declining, many are dying. In past decades, churches might decline to twenty or thirty people and linger at that size with flat vital signs. Their life support was infusions of money supplied by individuals or a denomination outside the church. (bl. 32)

'n Verslag wat voor die 69ste Algemene Kervergadering (AKV) van die Nederduitsch Hervormde Kerk van Afrika (NHKA 2010a:230) gedien het, weerspieël dieselfde tendens in die NHKA. Hierdie verslag meld dat die NHKA se lidmaatgetalle die afgelope dertig jaar met ongeveer 35\% verminder het terwyl die getal diensdoende predikante in dieselfde tyd met ongeveer $40 \%$ gedaal het, asook dat dooplidmate in die laaste twee dekades met meer as 50\% gedaal het. Dit sal luidens die verslag daartoe lei dat die NHKA binne 20 jaar dramaties kleiner sal word. Hierdie daling is statisties identies aan wat die Nederduitse Gereformeerde Kerk en die Gereformeerde Kerke in Suid-Afrika (GKSA) beleef. Trouens, dit is 'deel van 'n wêreldwye verskynsel onder tradisionele Reformatoriese kerke' (NHKA 2010a:230).

Die verslag voer verder verskeie redes en faktore aan as rede vir die agteruitgang van die Kerk en die krisis wat die Kerk het om by die wêreld uit te kom. Interne faktore wat 'n rol speel word aangedui as emigrasie van lidmate, lae geboortesyfer, veroudering van lidmate, gebrekkige geloofsopvoeding van kinders deur ouers, gebrekkige opsig en bearbeiding van bestaande lidmate, oneffektiewe bedieningsstrukture asook eredienste wat nie altyd die jeug bereik nie. Daarbenewens is die tyd van tradisionele lidmaatskap verby. Mense verwissel baie maklik van die een kerk na 'n ander. Mense raak maklik onkerklik. Daar is ook by baie gemeentes 'n gebrek aan missionale bewussyn wat gelei het tot die inkrimping van gemeentes. Bogenoemde lei volgens die verslag tot die onvermoë van gemeentes om finansieel lewensvatbaar te wees, asook strukturele beperkinge met betrekking tot die neem van effektiewe besluite deur liggame soos die Raad van Finansies en die Pensioenraad (vgl. NHKA 2010a:231). 
Die verslag identifiseer verder ook eksterne faktore soos die ingrypende sekularisasie van die Suid-Afrikaanse gemeenskap, die rol van die media en die aanvaarding van ander godsdienste as legitieme alternatiewe vir die Christendom, politieke, ekonomiese en sosiomaatskaplike veranderinge, en tegnologiese ontwikkeling.

Minder ooglopende redes vir die agteruitgang van die tradisioneel reformatoriese kerke het luidens die verslag te doen met dominante denksisteme, (vgl. Armour \& Browning 2006:16 verv.), teologiese uitgangspunte en etos van die kerk (vgl. Gaum 2011:26 verv.; König 1998:36 verv.) wat die verkondiging van die evangelie bemoeilik. Wêreldwyd blyk dit die tradisionele reformatoriese kerke se grootste probleem te wees. Gevolglik het die Kerk se roeping om die evangelie aan alle mense te verkondig, juis die kerk se grootste krisis geword het (vgl. NHKA 2010a:231).

Die NHKA (2010a) het van hierdie krisis kennis geneem. Dit blyk onder andere uit die volgende:

In ons eie tyd moet dit nog meer radikaal gestel word: nie net is wat die kerk doen problematies nie, maar die kerk opsigself het problematies geword. Sommige teoloë meen dat kerke en denominasies so vreemd vir die mens van die 21ste eeu geword het, dat kerk (in hulle tradisionele gestalte) nie die evangelie sinvol aan onkerklike en ongelowige mense kan verkondig nie. Nelus Niemandt skryf in 2007 dat tradisionele kerke nie enige kans in die post moderne wêreld het nie ... en ry selfs die koninkryk van God in die wiele. Peter Ward stel in 2002 die radikale vraag: 'The question is whether our churches are part of the problem or part of the solution'. (bl. 232)

Terwyl daar aan die een kant wêreldwyd konsensus is oor die feit dat die tradisioneel reformatoriese kerke in ' $n$ krisis verkeer, is daar aan die ander kant nie eenstemmigheid oor wat die kerke te doen staan om hierdie krisis die hoof te bied nie (vgl. Van der Merwe 2014:870).

\section{Van beweging tot instituut}

David Bosch het reeds in 1993 daarop gewys dat die vroeë Christelike kerk uiteindelik sy karakter as beweging sou verloor en onvermydelik 'n instituut sou word. 'Either the movement disintegrates or it becomes an institution - this is simply a sociological law' (Bosch 1993:52 verv.). Wat betreurenswaardig is, is nie soseer dat die beweging geïnstitusionaliseer is nie, maar dat toe dit gebeur, die kerk baie van sy entoesiasme verloor het:

Its white-hot convictions, poured into the hearts of the first adherents, cooled down and became crystallised codes, solified institutions, and petrified dogmas. The prophet became a priest of the establishment, charisma became office, and love routine. The horizon was no longer the world, but the boundaries of the local parish. The impetious missionary torrent of earlier years was tamed into a still flowing rivulet and eventually into as stationary pond. It is this development that we have to deplore. Institution and movement may never be mutually exclusive categories: neither may church and mission. (Bosch 1993:53; kyk ook Van Aarde 1995:63)
Die probleem ontstaan wanneer die kerk struktuur en wese met mekaar verwar. Sodoende gebeur die onvermydelike, naamlik dat die instandhouding van die struktuur gesien word as beskerming van die wese van die kerk. Reeds in 1995 het Koekemoer (1995:597) op die gevaar gewys dat wanneer die sigbare empiriese grootheid op hierdie wyse losgemaak word van die kerk as gebeure, daar verstarring intree wat eindig in 'n lewelose instituut waarin wette en bepalings die oorheersende rol speel. Wanneer die instandhouding van 'n gemeente of kerk die enigste doel van God se koms na hierdie wêreld gemaak word, word nie ' $n$ gemeente nie, maar ' $n$ klub van 'eendersvoelendes' en 'eendersdenkendes' gebou. Koekemoer (1995) se waarskuwing moet vandag ernstiger as ooit geneem word:

Wie dus kerk hoofsaaklik as instituut sien, maak die teenwoordigheid van Christus verlede tyd. Dat so 'n beskouing skrikwekkende gevolge vir die lewe van die kerk inhou, hoef nie eers beredeneer te word nie. (bl. 600)

'n Tipiese probleem van kerke by wie die instituutkant sterk ontwikkel is, is dat die kerk baie bewus van homself, sy eie behoeftes en sy eie beeld is (vgl. Burger 1992:13). Dulles (1987:41) tipeer hierdie probleem soos volg: 'The beneficiaries of the church, in the institutional model, are its own members.'

Burger het reeds 1997 daarop gewys dat waar 'n groot deel van 'n gemeente of kerk se energie en krag gebruik word om homself in stand te hou en te kontinueer, gebeur dit maklik dat so 'n gemeente of kerk die sin van sy bestaan, naamlik sy selfverloënende gerigtheid op die wêreld, uit die oog verloor en verloën sonder dat hy bedoel om dit te doen. Waarna, volgens Burger (1997:41) gestreef moet word, is 'n balans tussen die instandhouding van die kerk as instituut en die kerk se gerigtheid op die wêreld. Wanneer die gemeente of kerk so gestruktureer word, sal die instituut nie'n magsfaktor wees wat sy totale kerkwees oorheers nie.

Hendriks (1992:18-34) toon die volgende gevare van die instituutmodel aan:

Dit het 'n swak skriftuurlike en vroeg kerklike basis. Tradisie speel 'n oorheersende rol. Die hiërargiese struktuur en die mate waarin die instituut se belange alles oorheers is een van die negatiefste kenmerke van hierdie model. Alle inisiatief word 'van bo' verwag. Vernuwing is baie moeilik, aangesien alles eintlik deur die gemeente of kerk se etos bepaal word en deur sy kerkorde gereël word, of andersins deur die kerkleiding hanteer word. Die pneumatologie in hierdie model is swak ontwikkel. Lidmate se gawes word nie benut nie. Die eskatologie is nie ontwikkel nie. Die perspektief van God se koninkryk vind nie baie ruimte nie, want eintlik is die koninkryk van God in die kerk teenwoordig (vgl. Snyder 1991:67-76; Borg \& Scorer 2006:40 verv.). As sodanig het hierdie model altyd 'n meerderwaardige houding van selfgenoegsaamheid waar daar nie veel ruimte vir ander kerke se siening is nie daarom is die ekumene ook baie swak ontwikkel (kyk Van der Merwe \& Beukes 1997). 
Daar is min twyfel dat die probleme wat eie is aan ' $n$ model wat beskryf kan word as 'n kombinasie van die instituut- en die verkondigingsmodel tans van die belangrikste redes is waarom die missionale gerigtheid van die NHKA nog nie werklik inslag in die bediening van gemeentes kon vind nie. Hendriks (1992) som die negatiewe kenmerke van die verkondigingsmodel soos volg op:

Die eensydige konsentrasie op die heilswerk van Christus, ten koste van die belangrike gesigspunt van die heilswerk van die Heilige Gees. As gevolg van die baie aanvegtinge het die groot klem van die Reformatoriese kerke op die Woord, op lering, op die beginsel en teorie daaromtrent geval. Dit het meegebring dat die praktyk, die vleeswording van die Woord, nie altyd die aandag gekry het wat dit verdien nie. Dié swak balans kan daartoe lei dat die Woord dieselfde magiese karakter kry as wat die sakramente by Rome ontwikkel het. (bl. 23)

Die gebrek aan die dienskarakter by baie tradisioneel reformatoriese kerke is waarskynlik te wyte aan die oorbeklemtonings van sekere aspekte van die tradisionele reformatoriese teologie. Volgens Burger (1991:134) het juis dít daartoe gelei dat baie van die tradisioneel reformatoriese gemeentes of kerke 'n model gekies het waar die instituutgedagte oorheersend is.

Hirsch en Altclass (2009:209) beskryf institute soos volg: 'Institutes are organizations initially set up in order to fill a necessary religious and social function and to provide some sort of structural support for whatever function it needs.' Die probleem kom wanneer institute by die bloot strukturele ondersteuning verby beweeg en gesagsliggame van een of ander aard word. Dit is wanneer institusionalisme sy verskyning maak:

[I]nstitutionalization occurs when we outsorce an essentially grassroots/local function to a centralized structure/organization. Over time the centralized stucture tends to become depersonalized and becomes restrictive of deviating behaviour and freedom. In other words, it occurs when in the name of some convenience we get others to do what we must do ourselves. (Hirsch \& Altclass 2009:209)

Vir 'n volledige bespreking van die historiese ontvouing van die institusionele benadering tot kerkwees sien Dreyer (2011:132-133).

Ter wille van die bewaring van die sola fide en sola gratia het die kerke van reformatoriese belydenis dus 'n Pauliniese geloofsbegrip gekies sonder om die kontekstuele en tendensieuse aard van Paulus se teologie genoegsaam te verreken. Paulus het dit in die situasie nie nodig geag om hierdie beklemtonings altyd te balanseer met die ander aspekte van die geloof nie. Die balanserende beklemtonings word egter wel gevind in ander Nuwe Testamentiese boeke soos Matteus en Jakobus. In die reformatoriese teologie se gesistematiseerde aanbieding van die waarheid van die evangelie staan geloof normaalweg teenoor die werke. Dit is jammer, omdat werke op 'n ander manier ook onontbeerlik vir die geloof is. Hierdie verduidelikings slaag egter nie altyd daarin om die onderskatting van die daad-aspek van geloof te verhoed nie. Daar blyk talle lidmate in kerke van reformatoriese belydenis te wees wat nie regtig verstaan hoe wesenlik dade in 'n lewe van diens deel is van die geloof in Jesus Christus nie (vgl. Hendriks 1992:23).

Die gevaar is dus dat daar tussen die gemeente of kerk as gedefinieerde subjek en die gemeente of kerk as empiriese subjek in ' $n$ bepaalde tyd en op ' $n$ bepaalde plek 'n groot kloof kan wees. 'n Gemeente of kerk behoort deurlopend te vra hoe die gemeente of kerk as empiriese subjek steeds nader kan kom aan die gemeente of kerk as gedefinieerde subjek. Nel (1994:12) maak tereg die opmerking dat daar geen plek is vir'n gemeente of kerk wat nie steeds meer word soos hy reeds in Christus en deur die Gees is en soos hy deur God geroep is om te wees nie.

Dat daar in die NHKA juis hieraan 'n dringende behoefte bestaan, word al vir 'n geruime tyd deur navorsers aangetoon. Daar is gewaarsku dat die probleme waarmee die kerk veral op die terrein van die apostolaat worstel, te wyte is aan die manier waarop die NHKA oor homself dink. Begrippe soos verstarring, gearriveerdheid, selfvoldaanheid en onbuigsaamheid is gebruik om die NHKA se denke oor homself te beskryf (vgl. Van Wyk 1996; Velthuyzen 1988:512). Van Wyk (1996) beskou hierdie soort verstarde denke as 'n klad op die naam van die NHKA en roep die Kerk tot aksie deur te sê:

Kom ons onderneem voor God en teenoor mekaar dat ons dit nie langer wil laat voortduur nie. Die branding van die tyd waarin ons ons bevind, sluit ander gesindhede uit. (bl. 160)

\section{Basisteorie, praktykteorie en bedieningspraktyk}

Sleutelbegrippe soos basisteorie, praktykteorie en bedieningspraktyk word volgens Hendriks (1992) soos volg gebruik:

Die basis-teorie sê wat kerk is en wat God met die kerk beoog, die praktykteorie sê hoe die kerk homself moet organiseer om aan die Godgegewe doel te beantwoord en die bedieningspraktyk is ' $n$ beskrywing van die letterlike situasie, hoe die kerk op die oomblik funksioneer. (bl. 38)

'n Aspek wat uit die huidige bedieningspraktyk van die NHKA blyk, is soos reeds aangetoon, die oorheersende nabinne-gerigtheid van die Kerk. Van Wyk (1996:159) is van mening dat die na-binne-gerigte gespook om oorlewing juis dit wat vermy wil word, onafwendbaar nader bring.

Van 'n missionale lewenswyse as bedieningspraktyk, was en is daar in die NHKA feitlik geen noemenswaardige sprake nie. Die Kerk (elke gemeente) sal dringend moet leer dat die bestaansdoel van ook die NHKA impliseer dat:

[S]ending en evangelisasie nie primêr ' $n$ aktiwiteit van die Kerk is nie, maar van God self. Die missie waarmee God besig is, sluit wel die kerk in. Die missio Dei is God se aktiwiteit. Dit sluit beide kerk en wêreld in en is 'n aktiwiteit waarin die kerk bevoorreg is om in te deel. (Nel 1994:28) 
Van Wyk (1996) sluit hierby aan:

Daar moet ' $n$ gerigtheid kom op die wêreld en die nasies. Kerklike strukture en bepalings wat hinder, moet opgeruim word. Die kerk moet in gehoorsaamheid aan Christus se bevel met die evangelie na al die nasies gaan. (bl. 159)

Die bedoeling hiervan is duidelik. Die kerk sal moet besef dat die tyd van die sogenaamde kulturele Christendom se verdwyning reeds in ' $n$ ver gevorderde stadium is. Callahan (1990:3) het bykans drie dekades gelede al gewaarsku: 'The day of the professional minister is over. The day of the missional pastor has come.' Die Kerk (elke gemeente) behoort dus gelei te word om te verstaan dat God die Kerk (elke gemeente) roep om die evangelie met woord en daad te kommunikeer. Die Kerk se missionale selfverstaan moet voortvloei uit ' $n$ besorgdheid oor die vraag of, en hoe die NHKA beantwoord aan God se doel daarmee. Wat die NHKA betref is dit bekend dat die Kerk 'n bepaalde beskouing oor homself handhaaf. Koekemoer (1990) skets dit soos volg:

Ter wille van die waarheid wat die kerk moet verkondig en dien, is so ' $n$ beskouing van homself van wesenlike belang. Ook in dié opsig moet hy kategeties aan sy lidmate sê hoe hy homself sien en apologeties homself afgrens teen beskouinge wat, volgens sy oortuiging, die waarheid nie dien nie. Normaalweg is dit so dat die kerk sulke beskouinge in sy belydenis verwoord. Ten opsigte van die NHKA verloop die saak ook nie anders nie. (bl. 708)

Volgens Koekemoer (1990) is die kerk uitgesproke dat hy homself in die eerste plek sien as kerk van Jesus Christus. Daarnaas sien die NHKA homself ook as volkskerk:

Met volkskerk bedoel ons vandag in ons geval, in die woorde van prof J.P. Oberholzer: Volkskerk wat solidêr is met die volk (vergelyk Moses, Hosea, Paulus, Rom 9:3). Verder, volkskerk wat in die midde van die volk staan, midde in die politiek, kultuur, ekonomie en gemeenskapslewe van die volk - maar dan as apostel, met die proklamasie van die Godsheerskappy, as dienaar en getuie van die Godsgemeenskap. Dus nie volkskerk in die sin van volksomsluitende kerk nie en ook nie 'n kerk wat deur kultuur omsluit word nie. (bl. 709)

Die kerk ná Pinkster wat dieselfde is as vóór Pinkster is nie meer verbonde aan één volk nie, maar gerig op alle volke, stamme, nasies en tale. Die verwysing na 'apostel' in bogemelde aanhaling van Koekemoer is veelseggend. Die kerk sien homself nie meer as kerk van 'n volk nie, maar as kerk vir alle volke. Die kerk wil dus aan elke spesifieke volk sê: Luister, Israel, die Here ons God, Hy is die enigste Here (Deut 6:4):

Die NHKA besef dat met die volkskerkgedagte ... mag die kerk nooit op so 'n wyse een met die volk word dat sy verbondenheid aan sy Heer in gedrang kom nie. Omdat sy verbondenheid aan sy Heer vir hom van soveel wesenlike belang is, moet hy altyd gestalte van die een, heilige, algemene, Christelike kerk wees. Dit beteken dat die wesenskenmerke van die kerk altyd sonder meer op die volkskerk van toepassing moet wees. (Koekemoer 1987:16)

Die vraag hier is, kan die Kerk beide volkskerk en Kerk van Jesus Christus wees, sonder die gevaar van reduksionisme (sien later), of staan die kerk voor die onvermydelike keuse om slegs Kerk van Jesus Christus te wees?

\section{Die kerk se missionale selfverstaan}

Die verslag wat voor die 69ste AKV gedien het se bedoeling was om "n verdere verfyning van die apostolaatsbeleid teen die agtergrond van bepaalde teologiese vertrekpunte, die Kerkorde en die besluite van die 68ste Algemene Kerkvergadering' te wees (NHKA 2010a:229). Die AKV het ten opsigte van die verslag soos volg besluit: 'Die vergadering betuig dank en instemming met die wyse waarop die Raad vir Apostolaat uitvoering gegee het aan die opdragte van die 68ste Algemene Kerkvergadering' (NHKA 2010b:85).

In die verslag waarvan die AKV 'met dank' (vgl. NHKA 2010b:85) kennis geneem het, word gestel dat die Kerk, indien die Kerk sy groeikrag wil herwin en nie meer in 'n verleentheid geplaas te word met die opdrag van die Here nie, kerkhervorming (bekering) nodig is. Dit is trouens ook die bedoeling van die artikel in die Kerkorde 5.7.1 onder apostolaat, wat die Kerk oproep om voortdurend te hervorm (NHKA 2013). Hierdie werklikheid het die reformatore van die sestiende eeu helder en duidelik ingesien. Daarom het hulle met ' $n$ proses van kerkhervorming begin en die opdrag nagelaat: Ecclesia reformata, semper reformanda! Die kerkhervorming van die sestiende eeu word trouens beskou as 'n klassieke voorbeeld van ' $n$ transformerende benadering tot kerkwees (Dreyer 2011:133).

Kerkhervorming beteken dat die Kerk op grond van die Woord van God, al meer en voortdurend moet word wat dit in Christus reeds is. Ons glo, op grond van die Skrif, dat die Kerk voortdurend die volgende moet word (vgl. NHKA 2010a:235): Die volk van God wat in die wêreld van Hom getuig en tot sy eer leef, en die samelewing bedien met die versoeningsboodskap naamlik dat daar vrede tussen God en mens, en mens en mens gekom het, deur die versoeningslewe van Jesus Christus. Die huisgesin van God die Vader, wat uit sy hand leef en mekaar as broers en susters versorg. Die liggaam van God die Seun, wat een is met Christus en diensbaar word. Die tempel van God die Heilige Gees, wat Geesvervuld onder sy leiding die evangelie verkondig en die Here aanbid.

Kerkhervorming verg vanselfsprekend 'n voortdurende hartsverandering van elke lidmaat en ampsdraer van die kerk. Robinson (2008) oordeel dat 'n hartsverandering oor veel meer gaan as blote vernuwing:

The civic faith that was operative in many of our congregations for so many years was a compound of good citizenship, personal moral virtues, and doing what we could do to make the world a better place. Of course, there's nothing wrong with that; it's just that there's nothing specific Christian about it. Merely renewing civic faith will not get us headed in the right direction. Something more - something deeper - is required. (bl. 61)

Wat nodig is, is 'n nuwe hart (vgl. Robinson 2008:61-79). 'n Kerk wat erns maak met die Skrif sal vanself en voortdurend 
hervorm. Hervorming vind plaas wanneer die Heilige Gees, deur die Skrif, ons denke vernuwe, sodat ons kan onderskei waarop dit in die kerk aankom (vgl. Rm 12). Dit wat hier bedoel word is wat Robinson (2003) beskryf as:

And although mainline Protestant Churches may be reluctant to use the word, what I am talking about is 'conversion': turning around, being born anew, changed, made anew, given a new heart and a new mind to become followers of the Ons who makes all things new. (bl. 32)

Metanoia is altyd meer as praattaal. 'Dis 'n lewende verbintenis op eerstetaal-vlak aan Jesus en alles waarvoor Hy staan. Meta-nous-mense is "nuwe kop en hart"- mense en volg Jesus enduit en al die pad' (Joubert 2009:71). Dit impliseer dat die kerk nie geroep is om met homself besig te wees nie, maar met die wêreld. Juis in hierdie benadering tot kerkwees lê die potensiaal van groei opgesluit. Kerkhervorming vra onder andere veral ook dat gemeentes 'n missionale lewenstyl sal ontwikkel (NHKA 2010a:235). Dit vra dat gemeentes hulle brood op die water sal werp. Dit gaan al minder om oorlewing, en al meer om diensbaar te wees deur die apostolaat en die diakonaat.

\section{Missionale bediening}

Die term missionaal word gebruik om 'n baie spesifieke tipe gemeente, kerk, leierskap, Christendom, bedienings en so meer te beskryf. Byvoorbeeld, 'n missionale gemeente is 'n gemeente met 'n primêre verbintenis aan die missio Dei. Missionale leierskap is daardie vorm van leierskap wat die voorrang van die missionale roeping van God se mense beklemtoon. 'n Missionale gemeente is 'n gemeente wat sigself definieer in terme van die missio Dei, en wie se hele bestaan en werksaamheid georganiseer word rondom die gemeente se eintlike bestaansdoel:

When the church is in mission, it is the true church. The church itself not only is a product of that mission, but it is obligated and destined to extend it by whatever means possible. The mission of God flows directly through every believer and every community of faith that adheres to Jesus. To obstruct this is to block God's purposes in and through his people. (Hirsch \& Altclass 2009:212)

In die apostolaatsteologie word dus sterk onderskeid getref tussen die begrippe missionêr en missionaal. Sien in hierdie verband Peterson (2013):

In order to avoid the historical baggage that comes with the term missionary, the adjective missional was adopted to emphasize the essential nature and vocation of the church as God's called and sent people an understanding of the church that is supported by the New Testament witness. (bl. 84)

Missionêr dui op 'n eksterne gerigtheid, waar die fokus val op projekte en sendingwerk wat elders gedoen word. Missionaal dui op 'n denk- en bestaanswyse waar die missionaat ' $n$ integrale deel van 'n gemeente uitmaak. Dit dui dus allereers op 'n interne saak wat ten diepste met die spiritualiteit van lidmate en die gemeente te doen het, maar tweedens ook (vanselfsprekend) uitmond in diensbaarheid in die wêreld.
Dit is belangrik om te verstaan dat die byvoeglike naamwoord, missionaal, die diskoers waarin vroeër na kerk en sending verwys is, binne ' $n$ totaal nuwe raamwerk plaas (Van Gelder 2007:27). Die uitdrukking 'kerk en sending' kan 'n digotomie veronderstel waaraan moeilik ontsnap kan word, behalwe deur voorrang te verleen aan die een bo die ander. Die begrip 'missionale kerk' stel die kerk voor as missionêr in wese (vgl. Van der Merwe 2011:5 of 9).

Die volgende gevaar moet dus deurentyd in gedagte gehou word:

The term missional came into broad use after a small group of missiologists published Missional Church: a Vision for the Sending of the Church in North America in 1998. The term immediatly became a cliché that today means everything or nothing. (Hirsch \& Catchim 2012:xv)

Dit is dus van wesenlike belang dat die kerk sy gebruik van begrip missionaal reg sal verstaan en daadwerklik sal implementeer. Die blote gebruik van die begrip missionaal in kerklike geskrifte en gesprekke beteken opsigself absoluut niks.

'n Missionale gemeente of kerk is dus 'n gemeente of kerk wat sigself definieer, en die gemeentelike of kerklike lewe organiseer rondom sy bestaansdoel as agent van God se missie in die wêreld. Binne die reformatoriese tradisie word verstaan dat die kerk in die eerste plek die plaaslike gemeente is waar lidmate rondom die Woord en die sakramente vergader om die verlossing in Christus te vier. Dit is ook deur die plaaslike gemeente dat lidmate diensbaar word en in die wêreld getuig van die verlossing in Christus. Verder word bekeerlinge en gelowiges in die gemeentes van die kerk opgeneem. Dit is duidelik dat die apostolaat sy vertrekpunt het in 'n gemeente se gehoorsame luister na Christus se groot opdrag. Hoewel die primêre fokus van die apostolaat nie die uitbreiding van die kerk is nie, maar eerder die uitbreiding van God se koninkryk, is dit tog so dat die apostolaat ook lei tot die groei en die vooruitgang van die plaaslike gemeente (Van der Merwe 2009).

As gevolg van 'n bepaalde beleid, was $90 \%$ van die NHKA se apostolaat in die verlede gereduseer tot sinodale- en ringsaksies (vgl. NHKA 2010a:236). Dit het meegebring dat gemeentes wat self min of geen aandag aan die apostolaat gegee het, in baie gevalle gestagneer het en selfs begin verval het. Die tyd het aangebreek dat die fokus van die NHKA se apostolaat verskuif vanaf sinodale- na gemeentevlak (Van der Merwe 2009). Gemeentes moet daarom aangemoedig en gelei word om missionaal te leef. Missionale bediening wat fokus op die wese en roeping van die Kerk in die lig van die Woord sal onder andere ook fokus op: Lewende verhouding met God; deurleefde Christenskap; die koninkryk van God; 'n relevante en toepaslike bedieningspraktyk; geloofsonderskeiding onder leiding van die Woord en Gees; sistemiese denke; mense en verhoudings; die algemene priesterskap van die gelowiges (dissipelskap); rentmeesters wat belê in die bediening van die evangelie. 
Wanneer gemeentes 'n gesonde missionale lewenswyse en bedieningspraktyk ontwikkel, sal hulle in staat wees om hulle gestuurdheid uit te leef op so 'n wyse dat groei op verskillende vlakke in die gemeente sal plaasvind. As deel van hierdie strategie moet gemeentes toegelaat word om op eie inisiatief, met eie verantwoordelikheid en aan die hand van die roeping wat hulle ontvang het, gehoorsaam te wees aan die sending-opdrag. Dit is selfs wenslik dat geloofsgemeenskappe, met 'n eiesoortige bediening, gevestig word om postkerklikes en ander bekeerlinge te akkommodeer wat nie gemaklik voel binne die tradisionele bedieningstrukture van die NHKA nie. Elke gemeente en die Kerk as geheel, behoort 'n holistiese, geïntegreerde en omvattende benadering en strategie tot die apostolaat te handhaaf. Dit beteken dat die eredienste van gemeentes, die diakonaat, pastoraat en gemeenteontwikkeling alles te doen het met die apostolaat en omgekeerd. Dit is veral belangrik dat die kerklike diakonaat en apostolaat geïntegreerd funksioneer (kyk Peters 2000:54 verv.). Die apostolaat behoort dus 'n diensfokus te kry. Deur hierdie diens word die kerk God se dienskneg in die wêreld (Van der Merwe 2009; vgl. Deist 1989:894-915).

\section{Meervoudige groei}

Dit is vanselfsprekend dat die missionale gerigtheid groei impliseer. Dit is en bly immers die kerk se roeping om die evangelie aan alle mense te verkondig sodat al meer mense die knie voor God sal buig en sal bely dat Jesus die Here is. Dit impliseer groei. Groei gaan egter nie slegs om getalle nie, maar is meervoudig. Die volgende vorme van groei word onderskei: groei in geloofsvaardighede en lewensvaardighede; groei in bediening; inkarnerende groei (waar die kerk al meer gestalte vind en as liggaam van Christus funksioneer); deelnemende groei (groei in die getal mense wat deel is van die liggaam van Christus).

\section{Gesonde basisteorie}

Uit die verslae wat die NHKA tydens Algemene Kerkvergaderings oor die laaste aantal jare heen aanvaar het, blyk dit dat die Kerk erns gemaak het met die daarstel van 'n Bybelgefundeerde basisteorie, op grond waarvan die Kerk se roeping tot apostolaat verstaan en gedoen wil word. Vergelyk in hierdie verband die agendas van slegs die laaste drie Algemene Kerkvergaderings (NHKA 2004:296 verv.; NHKA 2007:60 verv.; NHKA 2010a:227 verv.).

Een beginsel is deurgaans gehandhaaf naamlik: dat die doel van die kerk uit sy wese afgelei moet word (vgl. Nel 1994:22). Omdat Christus die groot apostel (Gestuurde met volmag) is, is die kerk apostolies (gestuurde in opdrag) en omdat Christus Hoëpriester is, is die kerk offervaardig en omdat Christus die dienaar is, is die kerk dienend (vgl. Nel 1994:24).

In die NHKA se nadenke oor die apostolaat onderskei navorsers sonder uitsondering die kerk se Christusverbondenheid as wesenlik vir die nakoming van die apostolaatsroeping (vgl. o.a. Bosch 1993; Nel 1994;
Oberholzer 1985; Ott 1981; Van der Westhuizen 1992; Velthuyzen 1988).

Heinrich Ott (1981:424-428) sien die wese van die kerk daarin dat dit deel het aan die sending van Jesus Christus. Telkens waar die kerk gesien word as 'n gebeure waar Christus en die kerk in ' $n$ innige verhouding tot mekaar staan, het dit vir die kerk 'n drie-dimensionele betekenis, naamlik 'n gerigtheid na bo, na binne en na buite. Gevolglik mag daar nooit staties oor die kerk gedink word nie. 'The church of God must not stand still. In every age, inspired by the Holy Spirit, God's people have found new ways to express their fellowship and mission' (Ward 2002:1).

Die NHKA se geneigdheid om nie 'die Kerk se identiteit, teologiese etos, spiritualiteit en liturgie te wil verander nie omdat dit aan hulle 'n bepaalde geborgenheid en tuiste bied' (Dreyer 2003:1060) en daarom 'om te bly wat ons nog altyd was' (Buitendag 2008:125), lei egter daartoe dat gemeentes nie daarin slaag om nie staties oor die Kerk te dink nie.

\section{Die inkarnasie van Jesus Christus as praktykmodel}

Die missioloog Darell Guder (1999:xi), vestig die aandag op 'n opmerklike taal-innovering wat in die laaste aantal dekades na vore getree het wanneer van sending en evangelisasie gepraat word. Hy beskou die missiologiese geskrifte van John Mackay as eerste aanduibare tekens van hierdie innovering. Sedert Mackay vind Guder (1999):

$[A]$ growing emphasis upon following the 'model' of Jesus in evangelism and mission. Leslie Newbigin wrote about 'mission in Christ's way' in preparation for the 1989 World Conference on Mission and Evangelism in San Antonio. (bl. xi)

Hierdie terminologie is sedertdien goed gevestig in die ekumeniese gesprek oor sending. Die gesprek het dikwels saamgevloei met die parallelle klem op die inkarnasie van Jesus Christus as 'n teologiese interpretasie van die praktykmodel waarop sending gedoen moet word. Die fokus op die inkarnasie van Jesus Christus, die Woord wat vlees geword het, spreek ten minste twee groot en onderling verbonde bekommernisse aan in die huidige debat oor sending.

Dit is in die eerste plek 'n reaksie op die kritiek teen baie van die missionêre metodes en strategieë, wat beide die leer en handelinge waarin Jesus sy dissipels onderrig het, en waarvan Hy verwag het dat hulle dit sal voortsit, weerspreek:

The attempt to interpret mission in terms of the incarnation of Jesus suggests that the earlier European mission strategies should be replaced by a theology and praxis of mission rooted in and defined by the life and ministry of Jesus. (Guder 1999:xii)

In die tweede plek sal die fokus op die inkarnasie soos dit in die Skrif weergegee word, 'n skriftuurlike basis bied vir sending, wat die kwessies van motivering, inhoud en metode 
in direkte verhouding bring met lewe en die bediening van Jesus:

The why, what, and how of Christian witness are being explored exegetically in ways that most pioneers of Western mission would not have considered. This is linked with the rigorous rereading of the biblical records in terms of its first-century setting, made possible by the findings of historical, literary, and social approaches to scripture. (Guder 1999:xii)

Met inkarnerende sending word bedoel, die verstaan en praktyk van die Christelike getuienis wat gewortel is in, en gevorm is deur die lewe, bediening, lyding, dood en opstanding van Jesus. Hirsch (2006) sien Jesus se inkarnasie as verwysende na die daad van God waardeur God:

[I]n entering into the created universe and realm of human affairs as the man Jesus of Nazareth. When we talk of incarnational in relation to mission it means similarly embodying the culture and life of a target group in order to meaningfully reach that group of people from within their culture. I also use the term to describe the missionary act of going to a target people group as opposed to the invitation to come to our cultural group in order to hear the gospel. (p. 281)

Die begrip inkarnasie sluit alles van die Jesus-gebeure in soos wat dit in die Evangelies beskryf is, en soos wat dit in die Nuwe Testamentiese briewe uiteengesit is. Trouens, dit sluit alles in soos wat die ganse Bybel dit leer (vgl. Wright 2006:29 verv.). Inkarnasie is 'n selfstandige naamwoord wat die 'wat' van die evangelie opsom, soos wat dit gewortel is in die 'hoekom' van God se deernis met die skepping. In dieselfde asem is dit 'n begrip wat op 'n grondige manier die 'hoe' van die getuienis van die evangelie definieer (vgl. Guder 1999:4).

Die klem wat op die inkarnasie gelê word, handhaaf die geheimenisvolle karakter van God se werk soos wat dit voortgesit word in en deur die getuienis van die bemagtigde kerk. Dit is die Woord wat in die begin by God was, wat self God was (vgl. Joh 1:1 verv.), wat mens geword het, en wat sy skepsele in staat gestel het om sy heerlikheid te sien, vol genade en waarheid. Dat hierdie Woord mens geword het is 'n geval van goddelike genade. Die wyse waarop die geïnkarneerde Woord sigbaar, hoorbaar en kenbaar geword het in die lewe, dood en opstanding van Jesus Christus, openbaar die grootse en soewereine genade van God, soos wat dit God se doel midde in die menslike geskiedenis volvoer. Die kommunikasie van hierdie blye nuus is nou die kerk se roeping (kyk Joh 20:21). Die enigste manier hoe dit egter kan gebeur is deur die bemagtigende teenwoordigheid van die Heilige Gees (vgl. Peterson 2013:94, 121 verv.).

Dit is in die aardse bediening van Jesus waar die kerk leer hoe God se sending na Pase voortgesit word. Die beginsel is eenvoudig: Die Here Jesus Christus roep en vorm sy mense om sy getuies te wees. Die verhaal van die dissipels en hulle ervaring met Jesus tydens sy aardse lewe, is die essensiële kurrikulum vir die vorming van dié gemeenskap wat Jesus se bediening sou voortdra na Pase en Pinkster. Die wesenlike belang van dissipelskap vir kerkwees is duidelik uit Watson (1983:18) se opmerking: 'Discipleship sums up Christ's plan for the world. Yet for all its brilliant simplicity, it is the one approach that most Western churches have neglected'.

Die vorming van die aanvanklike dissipelgemeenskap loop op na die kruis en die leë graf. Die koninkryk wat Jesus verkondig, het 'n aanvang geneem op Paasmôre, toe die mag van die dood gebreek is, en die lewegewende regering van God die menslike geskiedenis in die opgestane Here binnegetree het. Dit was eers toe dat Jesus sy dissipels meegedeel het dat hulle sy 'gestuurdes' sal wees (kyk Joh 20:21; Matt 28:16 verv.). Wanneer daar teruggekyk word op die aardse bediening van Jesus, is dit duidelik dat Hy van meet af die dissipels geroep en voorberei het om sy getuies te wees (kyk Mark 3:13-15). In die begin, toe die twaalf hulleself slegs verstaan het as dissipels (leerlinge) van Jesus, het die evangeliste reeds hulle uiteindelike doel geteken as apostels (gestuurdes), getuies van alles wat God in Jesus Christus gedoen het. Jesus se missie het hulle missie geword (vgl. Kirk 2000:52 verv.). Met die oog hierop moes hulle egter eers saam met Hom wees. Hulle moes alles leer waarin Hy hulle onderrig het sodat hulle juis dit kon verkondig. Hulle moes die krag ontvang wat slegs Hy kon gee, sodat hulle die magte van die wêreld kan weerstaan in die naam van die soewereine Jesus (vgl. Guder 1999:5).

Die kritiese vraag vir die hedendaagse kerk is: Kan die unieke gebeure van die inkarnasie van Jesus steeds 'n konkrete betekenis hê vir die wyse waarop die kerk daardie boodskap vandag kommunikeer en sending doen? Guder (1999:xii) maak 'n sterk saak daarvoor uit dat die kerk, slegs deur sending inkarnerend te verstaan, sy apostolêre roeping op 'n effektiewe integrerende wyse sal kan uitvoer. Op hierdie wyse kan die kerk ook die tipiese Westerse reduksie van sending effektief teenwerk. Een van die talle probleme van die Westerse kerke is juis dat sending gereduseer is tot een van die baie programme van die kerk. Deur sending te sien en te verstaan deur die bril van die inkarnasie, kan die kerk gehelp word om sending te herdefinieer as wesenlik tot die roeping van die kerk:

Thus, the language of incarnational mission could be both constructive with regard to the biblical and theological understanding of the message, and polemical with regard to the context and history of mission, especially in Western tradition. (Guder 1999:xiii)

Vir Guder is die klem op inkarnerende sending op 'n unieke wyse integrerend van aard. Dit kan die kerk help om die twee wesenlike dimensies van die evangelie met mekaar te integreer, naamlik:

[T]he salvation event of Jesus's death and resurrection, and his preparation of his missionary people to carry forward into time and around the world the witness of that salvation. It can assure that the 'world' that God loves (John 3:16) will in fact hear the good news about that love. (Guder 1999:6)

Dit is belangrik om in gedagte te hou dat die boek Handelinge begin met Jesus se persoonlike ontmoeting met die dissipels, 
net voor sy hemelvaart. Daar deel die opgestane Heer hulle soos volg mee:

Maar julle sal krag ontvang wanneer die Heilige Gees oor julle kom en julle sal My getuies wees in Jerusalem, in die hele Judea en Samaria en tot aan die einde van die aarde. (Hand 1:8)

Vir die missionale teologie van Lukas-Handelinge (vgl. Guder 1999:6) is 'getuie' die term wat die praktiese werk beskryf wat gedoen moet word. Die term is die oorkoepelende beskrywing van die kerk se missionale roeping. Alles wat die Christelike gemeenskap is, doen, en sê moet verstaan word as uitdrukking van die kerk se getroue gehoorsaamheid aan die Here, en as uitdrukking van die Here se liefde vir die wêreld. Die hele Christelike gemeenskap word gedefinieer as 'n getuigende gemeenskap (vgl. Guder 1999:6).

God se Gees wat op geheimenisvolle en genadige maniere werk, bemagtig hierdie gewoon menslike en uiters feilbare getuies om middele te wees waardeur die mense die goeie nuus hoor, asook deur wie hulle uitgenooi word om volgelinge van Jesus te word. 'Want dit gebeur alles ter wille van julle, sodat die genade, wat steeds meer mense insluit, die dankbaarheid oorvloedig kan maak tot eer van God' (2 Kor 4:15).

Inkarnerende getuienis is daarom 'n wyse waarop die Christelike roeping beskryf word in terme van Jesus Christus as die boodskapper, die boodskap, en die model vir almal wat Hom volg. Om missionaal van die inkarnasie te praat is om dit wat Jesus was, gedoen het en hoe Hy dit gedoen het, in een groot gebeure te verbind wat alles definieer wat dit beteken om Christen te wees.

\section{Inkarnerende gemeentes}

Die kerk se selfverstaan as inkarnerende gemeenskap is gefokus op die kerk se bestaansdoel soos bepaal deur die Heer van die kerk. Dit opsigself het talle implikasies vir hoe veral die Westerse kerk se selfverstaan ontwikkel het. Soos wat die Westerse kerk poog om 'n missionale teologie te ontwikkel, is daar veral twee uitdagings ten opsigte van die gemeenskapskarakter van die inkarnerende getuienis.

Die eerste uitdaging is gerig aan die institusionele kerk van die Christendomera in al sy vorme. Indien Christus die kerk se bestaansdoel definieer, en indien die Christelike gemeenskap geroep is om die goeie nuus te inkarneer, mag nóg die instituut se bestaan nóg die onderhouding van die instituut, die kerk se prioriteit wees. 'Christ did not die only to save Christians, nor to form a church of the saved, but to bring Gods healing love to the world' (Guder 1999:24).

Die kerk en die verlossing van diegene wat die kerk uitmaak is bedoel om eersteling (vgl. Jak 1:18) van God se bedoeling met die hele skepping te wees. Sending kan daarom nie gereduseer word tot institusionele instandhouding nie, of in terme van hedendaagse krisis van die Westerse kerk, die kerk se oorlewing nie. Die kerk wys nooit na homself nie, maar altyd na Christus. Die kerk moet in lyn met Johannes die Doper, minder word en Christus moet meer word (Joh 3:30).

Dit is 'n onvermydelike historiese feit dat institute uiteindelik tot stand kom.

The formation of God's people is necessarily an institutional process, both in Israel and in the church. If this were not so, then the calling and sending of God's people would be a docetic, nonhistorical 'spiritual' process with little relavance to the world God loves. (Guder 1999:25)

Die probleem lê dus nie by die feit dát die kerk institusioneel is nie, maar by hóé die kerk institusioneel is. Jesus het tydens sy aardse bediening konsekwent die hoe van die institusionele vorme van God se uitverkore volk ernstig bevraagteken. In baie opsigte het die institusionele vorme van God se volk vandag egter weer die verloëning van die missio Dei geword. Guder (vgl. 1999:25) sien die Bybelse vertellings oor die optrede van die godsdienstige leiers en Jode van Jesus se tyd as tekenend van ons eie optrede. Hierdie beoordeling van godsdienstige leiers en Jode deur Jesus, dien as konstante oproep tot bekering vir almal wat verantwoordelik is vir die religieuse 'establishment'.

Die probleem is egter dat die institusionele kerk klaarblyklik 'n subtiele maar kragtige belang daarby het om die evangelie onder 'beheer' te bring, en om dit 'hanteerbaar' te maak. Guder sê: 'This has always been true' (1999:25). As bewaarders en begunstigdes van die instituut word die leierskap van die kerk deur die inkarnasiemandaat, uitgedaag om hulle funksionering baie krities te bevraagteken soos byvoorbeeld: Is ons gemeenskaplike institusionele lewe 'n beliggaaming van die goeie nuus? Openbaar die manier hoe ons lewe, geld bestee, gesamentlike besluite neem as organisasie, beide die karakter en bedoelinge van God vir die mensdom?

In die tweede plek daag inkarnerende sending die individualistiese neiging uit, wat die Westerse kultuur in baie gevalle kenmerk. Indien die evangelie slegs geïnkarneer kan word in en deur'n gemeenskap, moet die individuele Christene hulleself altyd verstaan in terme van hulle deel wees van die groter geloofsgemeenskap. Hy of sy is deel van 'n organiese geheel wat slegs lewe en funksioneer soos wat elkeen in die geloofsgemeenskap hulle wedersydse interafhanklikheid uitoefen. Dit maak natuurlik nie die individuele Christen se belewenis van die evangelie oorbodig nie.

As die kerk dus op inkarnerende wyse getuie van die evangelie wil wees, sal die kerk twee dinge volgens Guder (1999) baie ernstig moet neem:

[T] he way in which we relate as individuals to the corporate church. We will take just as seriuously the need to reflect critically and repentantly on the way the institution relates to its members. (bl. 26) 


\section{Die praktyk van 'n inkarnerende geloofsgemeenskap}

Die vraag is hoe word 'n inkarnerende geloofsgemeenskap gevorm? Die antwoord is: Dit gebeur wanneer die geloofsgemeenskap deur die Heer van daardie gemeenskap gevorm word.

Volgens Guder (1999:26) verskaf die Nuwe Testament die nodige inligting. 'We are called to follow the disciples into their experience with Jesus as their Teacher and Master, in order to carry on their apostolic mission.' In die Nuwe Testamentiese wêreld is dissipelskap verstaan as ' $n$ proses wat gekenmerk is deur 'n intieme en omvattende verhouding van leer, naleef en navolging. Jesus se dissipels het volgens die tipiese patroon van die rabbynse onderrig van daardie tyd, hulle gewone beroepe en roetine laat vaar, om saam met Hom te leef. Hulle het dissipels geword op grond van wat Jesus gedoen het. Hy het hulle geroep en uitgenooi om Hom te volg en om vissers van mense te word. Hulle het dus nie aansoek gedoen om sy dissipels te wees nie, hulle het gereageer op Jesus se roeping. Alles wat hulle van daardie oomblik af saam met Hom beleef het, was onontbeerlik vir hulle vorming. Hulle het dit wat Hy hulle geleer het gememoriseer, wat Hy gedoen het, onthou, en sy boodskap aanvaar as die doel en inhoud van hulle lewe. Hulle was dissipels van Jesus met die oog daarop om sy apostels te word, hulle was leerlinge van Jesus met die oog daarop om sy boodskappers te word. Om dissipel te wees, is dus nie ' $n$ doel opsigself nie, dit is in wese missionaal: Dissipelskap loop uit op die apostolaat, op 'n uitgestuurwees (vgl. Joh 20:21).

Hierdie basiese beginsel van inkarnerende sending vloei voort uit die intieme verhouding van dissipelskap. Dit is van kardinale belang dat 'n Christus-belydende kerk hierdie beginsel sal behou en bewaar. Guder (1999) se opmerking in hierdie verband moet met die grootste erns bejeën word:

The witness (both the 'persons as witnesses' and their 'impact as witness' - martyroi and matyria) is formed by Jesus Christ, whose work through the Spirit is the continuation in the gathered church of what he began with the first community of disciples. (bl. 27)

Hierdie uitgangspunt impliseer dat die verhouding wat die eerste dissipels met Jesus gehad het, voortgesit word in elke afsonderlike geloofsgemeenskap se verhouding met sy Heer (vgl. Guder 1999:27).

Die verlossing wat Christus bewerk het maak dit moontlik om op 'n totaal nuwe manier te lewe as God se volk, met nuwe hoop en vertroue in God, en met 'n nuwe doel as 'n gestuurde gemeenskap. Die etiek van missionale lewe is geleer in die konkrete situasies wat die apostels in hulle briewe aangespreek het. Die briewe het dus Jesus se manier om 'n missionale gemeenskap te vorm, voortgesit deur steeds van dissipels apostels te maak. Die verskillende briewe het die verskillende geloofsgemeenskappe deurlopend aangespreek deur taal te besig wat hulle inkarnerende karakter definieer. Kyk Romeine 1:17; 1 Korintiërs 1:2; 2 Korintiërs 1:1; Efesiërs 1:1; Filippense 1:1; Kolossense 1:1; 1 Tessalonisense 1:1; 1 Petrus 1:1-2. Die deurlopende tema van al hierdie begroetings is God se dade wat hierdie gemeenskappe in aansyn geroep het deur die apostoliese getuies, hulle identiteit as God se gekose volk (ekklesia), en hulle getuienis in die spesifieke kontekste waarin God hulle geplaas, en gevolglik ook gestuur het.

Vir die kerk beteken dit om die Bybel te lees vanuit die basiese aanname dat die Bybel bedoel is om die lidmate vir sending toe te rus. Dit beteken lidmate moet leer om die Bybel te lees binne die raamwerk van 'n missionale hermeneutiek. Inkarnerende getuienis is die gevolg van 'n voortgaande vertaling van Bybelse dissipelskap in die spesifiekesendingveldewaarindiekerkasgeloofsgemeenskap gestuur word. Waar ook al die Christelike geloofsgemeenskap homself bevind, en wat ook al die besondere uitdagings is wat die Christelike geloofsgemeenskap in die gesig staar, die opdrag bly steeds om die evangelie op so 'n wyse te vertaal dat die goeie nuus gehoor, gesien en op gereageer kan word. Die Christelike geloofsgemeenskap se getuienis definieer met ander woorde elke aspek van hulle lewe.

\section{Omvattende inkarnerende sending}

Om dissipel van Jesus Christus te wees definieer die volle spektrum van Christelike lewe. Hou egter in gedagte dat dissipelskap in getuie-wees moet uitmond. Gevolglik is inkarnerende getuienis allesomvattend vir die kerk van Jesus Christus. Getuie as die oorkoepelende begrip wat Christelike roeping definieer, dui op die allesomvattendheid van inkarnerende sending. Dit beskryf Christenwees beide korporatief én individueel. Dit definieer die aard van Christene se lewe as getuies (kyk Hand 1:8). So word die lewe van 'n Christelike geloofsgemeenskap sigbaar in 'n korporatiewe uitlewing van die evangelie: 'Dit is hoe almal sal weet dat julle my dissipels is - as julle liefde teenoor mekaar het' (Joh 13:35). Dit maak van elke aspek van Christelike gedrag ' $n$ instrument van God se kommunikasie (kyk 1 Pet 2:12).

Die praktyk van inkarnerende sending daag die hedendaagse kerk ook op 'n hele aantal ander punte uit, waar die kerk geneig is om die skopus van sy roeping in te perk. Hierdie inperkinge word aangedui as 'reductionisms' (vgl. Guder 1999:32). Hy sien hierdie inperkings as konstante herinneringe van die kerk se geneigdheid 'to conform gospel witness to expectations of objections that our world, our context, wants to impose upon the faith' (1999:32). Die dryfkrag van die Bybelse boodskap is uitdruklik holisties van aard. Die grondbetekenis van verlossing is immers genesing, wat onder andere beteken: Om wat gebroke is heel te maak. Wanneer die evangelie in terme van versoening gedefinieer word, verwys dit na die manier waarop God alle gebroke verhoudings herstel: Die verhouding met die Skepper, met ander skepsels, met jouself en met die natuur. Wanneer die evangelie in terme van verlossing gedefinieer word dui dit op die manier waarop God deur Jesus se dood sondaars vrymaak van die 
bande van sonde en 'n sinlose hooplose bestaan, met die oog op die heelheid, sin en lewensvolheid wat sy vryheid en hoop meebring. Wanneer die evangelie gedefinieer word in terme van vergifnis, dui dit daarop dat God al ons skuld verwyder en ons opstandigheid oorwin deur Christus se versoenende offer aan die kruis. In stede van verwydering van God, leef die kerk met die wete dat God sy kerk in 'n nuwe verhouding met Hom en sy ganse skepping gestel het (vergl. Guder 1999:32-33).

Hierdie heelheid het uitkringende dimensies wat verby die genesing van individue strek. God se verlossing in Christus heel ook die diep menslike verdeeldheid wat daar tussen rasse, nasies, geslagte en sosiale klasse mag wees. Dit oorwin die oënskynlik onoorkomelike versperring tussen Jode en Samaritane, en selfs radikaler, tussen Jode en heidene. Dit desentraliseer menslike sentra van mag en trek die kerk in, in 'n nuwe verhouding van diens en wedersydse onderworpenheid.

Dit verwerp enige afhanklikheid van mag en herdefinieer menslike interaksie radikaal, soos wat die kerk in staat gestel word om selfs die vyand lief te hê. Dit kyk eskatologies vooruit na wat beide die Ou en Nuwe Testament teken as die tyd waarin God se verlossende werk al die vyandigheid, wat die skepping so dikwels kenmerk, sal oorwin; kortom die nuwe hemel en die nuwe aarde.

Dit is nie moontlik om God se helende en verlossende bedoeling volledig te beskryf nie. Tyra verwys na die karakter van Jesus se inkarnasie as 'a mystery' (vgl. Tyra 2013:97-98). Inkarnerende getuienis is fundamenteel oop vir die voortgaande ontdekking van die verrassende maniere waarop God alles gesond en heel maak, alles waarvan die wêreld oordeel dat dit onmoontlik is.

Die omvattendste van al die evangelie se aansprake is: Jesus is die Here. Dit was ook die eenvoudigste en kernagtigste belydenis van die vroeë kerk. Dit is trouens ook die essensie van evangelie volgens die eerste Johannesbrief:

The lordship of Jesus Christ, to whom all authority has been given in heaven and earth, is a constant challenge to the world's security and vested interests. It is the crucial heart of the church's witness. But it is also the most diluted and reduced dimension of our evangelization. (Guder 1999:33)

Die roeping tot evangelisasie het van die kerk se kant af vele vorme van reduksionisme ondergaan. Die allesomvattende karakter van inkarnerende getuienis, is dikwels verloën deur die maniere waarop die kerk gekies het om evangelisasie te doen. 'We find that, as the church goes about its mission, there is constant division of what is not to be divided and neglect of what must be included' (Guder 1999:34).

Evangelisasie is in wese kommunikasie. Dit gaan daaroor dat die Bybelse verhaal bekend gemaak word. Die bedoeling is egter nie bloot om die goeie nuus woordeliks oor te vertel nie, dit is ook om diegene wat die boodskap gehoor het, uit te nooi om te reageer en om deel te word van die getuigende geloofsgemeenskap. Jesus se aardse bediening is die skool vir evangelisasie. Die kerk kan by Jesus se manier van verkondiging leer hoe divers en kreatief die evangelieverkondiging kan wees. Dit kan gebeur in die roetine gesprekke van die lewe van elke dag, in gelykenisse, in argumente, wanneer politiek bespreek word, ekonomie bedryf word, sosiale konflikte hanteer word, en uitleg van die Bybelse tradisie gegee word. Wat by Jesus in die Evangelies geleer kan word, is dat die verbale kommunikasie van die evangelie in verband staan met elke aspek van die lewe en die gemeenskap. Die boodskap van God se heerskappy verkondig dat:

$[T]$ he evangelistic message both states and demonstrates how all of life is confronted and embraced by God's saving purposes. Jesus teaches us and challenges us to tell the whole story when we communicate the gospel. (Guder 1999:34)

Die allesomvattende karakter van inkarnerende evangelisasie gaan verlore wanneer die evangelie slegs op individue, en hulle persoonlike verlossing gerig word. Wanneer van die evangelie'n hoogs individualistiese en private aangeleentheid gemaak word, terwyl die kerk die hoorder en potensiële bekeerling 'beskerm' teen die hoë eise van Christus se heerskap, word die evangelie tot 'goedkoop genade' gemaak (vgl. Bonhoeffer 1959:35 verv.). Sodoende word die evangelie weinig meer as 'n soort religieuse addendum tot die lewe van 'n individu, terwyl dit verder geen aanspraak het om 'n mens se lewe van binne uit te transformeer en te herskep nie.

Guder (1999:35) wys daarop dat inkarnerende getuienis verloën word wanneer die kommunikasie van die evangelie gefokus word op sekere aspekte terwyl ander geïgnoreer word. Dit gebeur wanneer die kerk se evangelisasie ingeperk word deur dinge soos ras, klas, geslag, opvoeding, welvaart of nasionaliteit. Inkarnerende allesomvattendheid gaan verlore wanneer die kerk se evangelie die dogma beklemtoon sonder om tegelyk die etiek te verreken, of deur die etiek te beklemtoon sonder om tegelyk die dogma te verreken. Die volle omvang van die inkarnerende boodskap word gekompromitteer wanneer daar 'n wig ingedryf word tussen die evangelie en sosiale geregtigheid. Die Jesus wat by geleentheid die tempel gereinig het, 'n owerspelige vrou vergewe het, saam met Samaritane geëet het, met die teoloë van sy tyd geredeneer het, én wat aan die keiser toegesê het wat die keiser toekom, is dieselfde Jesus wat aan die kruis vir die sonde van die wêreld gesterf het, en wat slegs geken kan word deur die belydenis van 'n twyfelende Thomas - my Here en my God. Die wyse waarop die kerk die evangelie kommunikeer moet deurlopend aan die Skrif getoets word, om vas te stel of die kerk nie moontlik dit skei wat nie geskei mag word nie. Dit is wat die praktyk, wat in baie kerke en gemeentes bekend gestaan het as 'wandel in die Woord', so onmisbaar vir kerke en gemeentes maak (kyk Marias 2007:9 verv.). Wanneer Christus mense roep om Hom te volg, mag daardie roeping nooit geskei word van die oproep om Hom as Here te dien nie. Die versekering van vreugde en vrede in die kennis van God se vergewende liefde in Christus mag 
nooit geskei word van die harde feit dat diegene wat Hom volg verwerping, vervolging en self marteling mag ervaar nie.

Soos wat die kerk stelselmatig uit die Konstantynse sisteem uit beweeg en terugkyk op eeue van wederkerige vennootskap tussen kerk, staat en gemeenskap, sal talle voorbeelde gesien kan word waar die kerk nie getrou was aan die inkarnerende alles omvattendheid van die kerk se gestuur-wees nie. Die inperkende klem op individuele verlossing het in baie gevalle hand aan hand gegaan met die verwaarlosing van Jesus se etiese gebooie. Dit kan vertolk word as 'n begeerte om die radikale eise van die evangelie uit die openbare sfeer te skuif en om dit uitsluitlik 'n dimensie te maak van die privaatheid van 'n mens se verhouding met God. Dit is hoe evangelisasie, volgens Guder, tans in baie gevalle funksioneer. Hy argumenteer dat die inkarnerende omvattendheid van die missio Dei sal ontluik wanneer die kerk die volgende verwaarloosde kwessies daadwerklik aanspreek (1999:35 verv.):

1. Jesus se bewys dat die evangelie God se krag is om elke dimensie van menslike gebrokenheid te genees. Jesus het in sy bediening nie onderskeid gemaak tussen fisiese en geestelike genesing nie. Die herstel van heelheid in elke dimensie van die menslike bestaan is die inkarnerende dryfveer in Jesus se bediening. Hierdie radikale verwagting vind wêreldwyd uitdrukking in die sending van nie-Westerse kerke. Guder (1999) se opmerking in verband hiermee is van belang:

There is a Western arrogance, fostered probably by the scientific certitude that emerges from the Enlightenment, that has taught us to be sceptical about such things as healing, miracles, and the transformation of individuals. As we continue to neglect the reality of comprehensive healing in the name of Jesus, we dilute and betray the incarnational wholeness of the gospel. (bl. 36)

Die Nuwe Testamentiese gemeenskap van Jesus volgelinge, is gekenmerk deur die deurlopende proses van heling. Die mees basiese van die inkarnerende omvattendheid van die missio Dei is dat die kerk self God se genesende liefde ervaar soos wat daardie liefde aan ander verkondig word.

2. Jesus se verwerping van alle vorme van geweld. Die Westerse Christendom het in ' $\mathrm{n}$ groot mate vrede gemaak met geweld en oorlog as legitieme wyses om bepaalde gewenste resultate te verkry. Hierdie is uiteraard 'n baie ingewikkelde onderwerp en nie iets wat in die bestek van 'n studie van hierdie omvang die nodige aandag kan kry nie. Oorlog en geweld opsigself rig egter ' $n$ duidelike uitdaging aan die integriteit van die kerk se inkarnerende getuienis. Die etiese gruwels van moderne oorlogvoering en in die besonder die kwessie van volksmoorde, vra van die Christengemeenskappe om hulle tradisies en teologie aan 'n eerlike en deurtastende skriftuurlike ondersoek te onderwerp.

3. Jesus se omkering van alle menslike strukture van mag en gesag. Die eeue waarin die kerk in die Weste betrokke was by strukture van mag en gesag, asook die voorregte wat die kerk in hierdie tyd beskore was, het die kerk verdoof vir die gevaar van die verslawende aard van hierdie kompromieë. Noudat die kerk sy plek en posisie verloor, is daar opnuut geleentheid:

[F]or the Western churches to examine their own structural and ethical concessions to the principalities and powers of wealth, prestige, competition and success. How can we learn, as mission communities, to immitate Jesus in the washing of the feet of his disciples? How can we become communities that share rather than dominate, that serve rather than rule? We neglect these compromises at the cost of loss of the incarnational comprehensiveness of the gospel and its transforming challenge to the world that is our mission field. (Guder 1999:38; vgl. Deist 1989:894; vgl. Sjogren 1993:87 verv.)

Die Groot Opdrag aan die einde van Matteus (28:18-20) word gekenmerk deur die terme 'alle', 'al', 'alles'. Soos wat'n geloofsgemeenskap by Jesus leer, en soos wat sodanige geloofsgemeenskap deur Hom gevorm word vir sy sending, ontdek die geloofsgemeenskap dat die Groot Opdrag in sy volheid uitgevoer moet word. Daar is oneindig meer aan die sending van Jesus as wat 'n geloofsgemeenskap in sy getuienis daarvan kan vertel. Die komprehensiewe karakter van inkarnerende sending konfronteer'n geloofsgemeenskap se gedeeltelike weergawes van die evangelie op 'n deurlopende basis. Soos die kerk in Handelinge (vgl. Peterson 2013:121 verv.), ontdek 'n geloofsgemeenskap deurlopend dat die sending wat hulle definieer altyd meer is as wat die geloofsgemeenskap aanvanklik geoordeel het. Hulle moet dikwels met groot moeite ontdek dat Jesus werklik bedoel het wat Hy by sy hemelvaart gesê het:

[M]aar julle sal krag ontvang wanneer die Heilige Gees oor julle kom en julle sal My getuies wees in Jerusalem, in die hele Judea en Samaria en tot aan die einde van die aarde. (Hand 1:8)

Tot hulle verrassing kon Samaritane volgelinge van Christus word. Tot hulle skok het God heidene, soos Kornelius, geroep om Jesus te volg. Volgens Joubert (2009:73) was dit die rede dat hulle Jesus tydens Paasfees vermoor het. Hy was te veel van 'n spelbreker. 'Min of meer alles wat heilig was, het Jesus verontheilig in die godsdientiges se oë: die Sabbat, die tempel, die grense tussen heilig en onheilig - jy noem dit!'

\section{Inkarnerende getuienis beliggaam God se liefde soos in en deur Christus geopenbaar en geleer}

Die uitgangspunt is dat die kerk geroep en bemagtig is om God se liefde in Christus te inkarneer. Jesus gee vorm aan sy gemeenskap van volgelinge om sy getuies te wees as uitbreidende beliggaming van God se liefde vir die wêreld (Joh 3:16). Soos elke aspek van dissipelskap vind die inkarnering van God se liefde nie outomaties plaas nie. Ons leer by Jesus wat God se liefde beteken, asook hoe om daarvan te getuig. Dit is waarom die Nuwe Testamentiese leer so dikwels imperatiewe gebruik:

The most comprehensive imperative in Jesus' formation of the missional church is the command to love. All the other 
imperatives directed to his followers can be understood as dimensions or aspects of the fundamental Christian witness the practise of the love of God made possible by Jesus' love at work in his followers. (Guder 1999:40)

Soos wat Jesus se getuies leer om die liefde wat Jesus hulle geleer en prakties gewys het, prakties uit te leef, begin hulle hul sending as geloofsgemeenskap te inkarneer. Die Sinoptiese Evangelies leer dat liefde die hart van die Evangelie verteenwoordig (Mark 12:29-31). Hierdie liefde word gedefinieer deur God se liefdeshandeling in Christus. Agape liefde is gevolglik ook die hart van elke handeling, wat daarop gerig is om God se goeie en helende bedoeling vir individue en vir die hele skepping konkreet te maak. Hierdie liefde doen vir die geliefde wat die geliefde nie vir hom- of haarself kan doen nie. Dit transformeer genade tot realiteit, dit vertaal ortodoksie in ortopraksie. Dit funksioneer op grond van die kragtige aanname dat God se kreatiewe goedheid en helende liefde die grondwaarheid is wat alle lewe omraam. 'To enflesh that love, in the frailest and most ambivalent of ways, is to be about the task of incarnational witness' (Guder 1999:40).

Die essensie van inkarnerende sending word saamgevat in die woorde van Johannes 13:34-35. Jesus is hierdie middelpunt waarom alles draai. Hy is die een wat gee, wat beveel, wat met sy lewe die voorbeeld stel en wat stuur. Vir Guder (1999) is hierdie teksgedeelte tekenend van Jesus se opdrag aan die kerk:

He addresses his church, represented by the plural 'you' of this text. His way of living with, teaching, and showing forth God's rule is now to become the church's way of going about its mission. (bl. 41)

Die doel hier is uitdruklik missionaal. Dit moet uit die geloofsgemeenskap se denke, beplanning en dade duidelik word dat hulle Jesus se dissipels is op grond van sy liefde wat in hulle lewe werksaam is.

Letterlik elke brief in die Nuwe Testament roep die kerk op tot gehoorsaamheid en getrouheid aan hulle roeping en beskryf dan hierdie roeping by wyse van imperatiewe waarvan die sentrale tema liefde is (1 Pet 1:22; Ef 4:2; Fil 2:2; Rom 12:9; 1 Kor 14:1; Kol 3:14). Dit is duidelik dat hierdie imperatiewe nie op die gelowige se eie bekwaamheid berus nie, ook nie dat dit goeie werke is waardeur hulle iets kan verdien nie. Hierdie imperatiewe is die gelowiges se aktiewe respons op die evangelie; ' $n$ respons wat moontlik gemaak word deur God se genade wat in hulle werk deur Jesus Christus. Die imperatiewe in die Nuwe Testamentiese briewe volg deurgaans op ' $n$ volledige uiteensetting van die indikatiewe van die evangelie (Rom 1-11; Ef 1-3; 1 Pet 1:1-12). Die imperatiewe is altyd aksies wat moet volg op dit wat God reeds gedoen het.

Om inkarnerende sending prakties te doen beteken om te ontdek dat Jesus 'n radikale nuwe lewe vir sy volgelinge moontlik maak. Dit is die bedoeling van Efesiërs 2:8-10. Die imperatiewe oor liefde leer die geloofsgemeenskap wat die 'goeie werke' is waarna hierdie teksgedeelte verwys, asook hoe om die goeie werke prakties te doen. Die inkarnering van God se liefde in Christus kry dus by uitstek gestalte (of nie) in die wyse waarin die geloofsgemeenskap as 'n geloofsgemeenskap funksioneer. Sien in hierdie verband Johannes 13:35. Die eerste vorm van Christelike getuienis teenoor 'n wêreld wat se oë hulle krities dophou, is die beliggaamde liefde van Christus, wat sigbaar in die geloofsgemeenskap werksaam is. Indien die wêreld nie kan sien dat liefde in die kerk as geloofsgemeenskap gestalte kry nie, is die kerk as geloofsgemeenskap ongehoorsaam, en word die wêreld beroof van die getuienis waaraan daar so ' $n$ dringende behoefte bestaan.

'n Goeie voorbeeld van die kommer oor die missionale integriteit van 'n geloofsgemeenskap se lewe, is Paulus se interaksie met die gemeente in Korinte. Hierdie geloofsgemeenskap as gedefinieerde subjek word beskryf as 'geroepe heiliges', wat 'in Christus geheilig is' (1 Kor 1:2); Paulus (1 Kor 1) sê:

Want deur Hom is julle in alle opsigte verryk in elke woord en in alle kennis. Net so is die getuienis oor Christus stewig onder julle gevestig, sodat julle terwyl julle wag op die openbaarmaking van ons Here Jesus Christus, nie in enige genadegawe tekort skiet nie. (vs. 5-7)

Die gemeenskap van gelowiges in Korinte as empiriese subjek is egter in die praktyk van hulle kerkwees onderling verdeeld, tolerant teenoor seksuele immoraliteit, daag mekaar voor die wêreldse hof, toegeeflik aan verleiding uit die heidendom, misbruik die nagmaal, verstaan die gawes van die Gees verkeerd, wat daarop uitloop dat hulle die gawes van die Gees misbruik, en Jesus se opstanding misken.

Paulus fokus baie van sy energie op hulle voortdurende bekering sodat hulle die evangelie met integriteit in Korinte kan inkarneer. Hy roep hulle konstant terug na die kruis en tot die bedoeling van hulle roeping en verduidelik die hulp wat hulle van die Gees in Christus het, sodat hulle hul roeping om heiliges in Korinte te wees met integriteit kan nakom. Teen die einde van die brief som Paulus alles op met die opdrag: 'Laat alles wat julle doen, in liefde geskied' (1 Kor 16:13). Dit is die kern van inkarnerende getuienis soos wat dit in die institusionele kerk gestalte moet kry.

Daar word dikwels verwys na 'onvoorwaardelike liefde' en na 'relasionele evangelisasie' as maniere waarop inkarnerende getuienis tot uitdrukking moet kom. Hoewel dit waar is, is die probleem dat hierdie uitdrukkings uitsluitlik verstaan word in ' $n$ privaat en individualistiese sin. Hoe belangrik dit ook al is dat die evangelie op individuele vlak geglo en geleef moet word, mag dit nooit die verantwoordelikheid wat die Bybel aan die geloofsgemeenskap as geheel opdra, verdring nie. 'n Slaggat waarin geloofsgemeenskappe dikwels trap, is om die evangelie individualisties te lees en toe te pas. Dit verwring in 'n groot mate die omvangryke betekenis van God se inkarnerende liefde. Die sigbaarmaking van God se werk kan 
nie bloot individualisties gedoen word nie. Dit kan slegs in en deur die gemeenskap van gelowiges wat Jesus Christus as Here bely, tot sy volle reg kom. Guder (1999) is reg deur op die volgende te wys:

The call to witness incarnationally to God's love means that we, in the West, must learn to read and hear God's word as a community and respond to it as a community. (bl. 44)

\section{'n Kerk met karakter}

Die Nuwe Testamentiese briewe lê klem op die karakter van die Christelike geloofsgemeenskap voor die oë van 'n dikwels vyandige wêreld. Voordat daar gekyk word na die wyse waarop die evangelie in die evangelisering van die wêreld geïnkarneer word, moet daar eers deeglik gekyk word na hoe die Christelike geloofgemeenskap self die evangelie geïnkarneer het. Dit is die eerste dryfkrag van inkarnerende getuienis, en dit beklemtoon die belangrikheid van kongruensie tussen hoe die geloofsgemeenskap as Christene prakties leef, en hoe hulle as Christene in die sendingveld (hulle eie konteks) teoreties getuig. Hierdie interaktiewe dimensies van inkarnerende getuienis is van fundamentele belang vir die uitlewing van die kerk se roeping.

Die inkarnerende betekenis van onvoorwaardelike liefde en verhoudings, binne en buite die geloofsgemeenskap kan gesien word in die eerste brief aan die Tessalonisense. Paulus, Silvanus en Timoteus verdedig hulle apostoliese bediening teenoor die geloofsgemeenskap van Tessalonika deur die integriteit van hulle werk te beklemtoon (1 Tess 2:7-8). Hulle getuienis was die inkarnering van daardie liefde wat uniek en finaal in Christus tot verlossing van almal geïnkarneer is. Sodoende het die evangeliste die geloofgemeenskap in Tessalonika bemagtig om op hulle beurt self ook die evangelie te beliggaam in hulle eie konteks.

'n Groot struikelblok is dat daar dikwels diepgaande en diepliggende weersprekings is tussen aan die een kant die boodskap van liefde wat die kerk verkondig, en aan die anderkant die liefdelose wyse waarop Christelike geloofsgemeenskappe onderling leef. Guder (1999:45) is van mening dat: '[T]this working out of the gospel of love in incarnational witness takes place in the ambiguity of human reality.' Die kontras tussen die 'wat' van die evangelie en die 'hoe' van die geloofsgemeenskap se getuienis skreeu dikwels om die geloofsgemeenskap se korporatiewe boetedoening en bekering. Hier kan gedink word aan etlike voorbeelde uit die geskiedenis soos: Die wrede dwang tydens die Middeleeue, waar die swaard en inhoud dikwels hand aan hand gegaan het; of die ongesonde koppeling wat daar baie keer tussen sending en kolonialisme was; of die hartseer inperkings van die evangelie wat gestalte gegee het aan afstigting van kerke dwarsoor die wêreld; of die verdeeldheid van die kerk wêreldwyd, waar feitlik elk van die hoofstroomkerke 'n skeuring van een of ander aard beleef het; of die harde werklikheid van baie agterdog in talle geloofsgemeenskappe waar strydende politieke belange gelei het tot onversoenbare botsings, binnegevegte en wedersydse veroordeling.
Daar blyk geen gebrek te wees aan voorbeelde van die Christelike geloofsgemeenskap se mislukking om 'so te leef dat julle die roeping waarmee julle geroep is waardig te wees nie' (Ef 4:1). Natuurlik is dit so dat Christelike geloofsgemeenskappe uit sondaarmense bestaan, maar dit moet onthou word dat dit sondaars is wat vergewe is. God se vergewende liefde konfronteer en transformeer die sondige menslike geloofsgemeenskap en roep hulle op tot berou en daaglikse bekering. Die geloofsgemeenskap inkarneer hulle getuienis tot liefde op geen ander wyse duideliker as in 'n eerlike erkenning van eie sonde, en 'n voortdurende groei in die volheid van die liefde waarvan hulle lewe nie. Met ander woorde, die geloofsgemeenskap beliggaam die evangelie van vergifnis en liefde soos wat hulle self vergifnis en liefde voor die oë van die wêreld leef. Dit is 'n deurlopende en opregte worsteling, soos wat dit die geval vir die geloofsgemeenskap in Filippi en Handelinge was. God se radikale liefde stel die Christelike geloofsgemeenskappe se liefdeloosheid asook hulle vermoë om hulle eie grense te stel, wat die betekenis en konkrete impak van God se liefdesboodskap inperk, telkens aan die kaak. Die kerk bestaan uit geheiligde sondaars en sondige heiliges, wat lewe met 'n konstante bewussyn van hulle verantwoordelikheid om daardie liefde waartoe hulle geroep en bemagtig is, op hulle beurt te deel met diegene na wie toe God hulle stuur. 'We need to experience the cleansing and restoring power of God's love so that we can be his agents' (Guder 1999:46).

\section{Vir alle mense}

Jesus het sy dissipels, en vir ons, geleer hoe die goeie nuus van God se liefde bekend gemaak moet word. Hy het, om mee te begin, alle mense ernstig geneem; soos gesien kan word in die geval van Saggeus in die boom, die ryk jongman, die Kanaänitiese vrou, of die Samaritaanse vrou by die put. Jesus het inderdaad 'n vreemde koninkryk gebring (vgl. Joubert 2009:99 verv.). Dieselfde kan gesien word in die inkarnerende betekenis van die apostels se verhouding met hulle gemeentes. Die Nuwe Testamentiese briewe weerspieël deurgaans die apostels se egte liefde en omgee vir die gemeentes waarby hulle betrokke was. Die getuienis van die evangelie het plaasgevind in die vorming van vriendskappe en die ontwikkeling van familie-agtige strukture, waar dit paslik was om van mekaar as broers en susters te praat. Guder (1999:47) wys egter daarop dat die klem op verhoudings, veral waar evangelisasie ter sprake is, kan lei tot 'n skeeftrekking van wat inkarnerende getuienis in wese beteken. Die fokus op verhoudings neig wetend of onwetend daartoe om 'n subtiele filtreringsproses in die praktyk van getuie-wees te word. Sonder dat dit noodwendig so bedoel word, is mense geneig om slegs verhoudings te bou met ander mense en groepe waarmee jyself gemaklik is, en saam met wie jy graag wil lewe. Die homogene beginsel waarop kerke hulle evangelisasie-aksies baie keer bou is begryplik as psigologiese en sosiale werklikhede. Hierdie beginsels speel egter uit in wat Guder 'culturally exclusive forms of Christian witness and church formation' noem, met as gevolg die 'pollution of Christian witness with racism, classism, and ethnocentrism' (1999:48). Die proses wat afspeel op die 
vlak van beide persoonlike ondervinding as die korporatief kulturele ontmoetings, mag psigologies en sosiologies verstaanbaar wees, maar dit is in direkte kontradiksie met die praktyk van getuienis wat Jesus geleer het.

In al sy verhoudings het Jesus die grense deurbreek van menslike voor- en afkeure, sosiale en politieke korrektheid en religieuse aanvaarbaarheid, wat die Palestynse gemeenskap van die eerste eeue gekenmerk het. Inkarnerende sending, soos beliggaam deur Jesus, het die aanvaarde modelle van interpersoonlike verhoudings en die vorming van gemeenskappe van sy tyd uitgedaag. Sy geboorte en sy Galilese wortels plaas Hom in die kader van die marginale figure van sy tyd. 'He was not identified with the religiously prominent and respected circles of his day. He came "from the wrong side of the tracks"' (Guder 1999:48).

Ook in sy keuse van dissipels het Jesus die patroon van inkarnerende omkering van die aanvaarbare norme en strukture van die samelewing, voortgesit. Hy het mense wat onrein was (vissermanne), nasionaal verdag (tollenaars), en polities twyfelagtig (selote) as dissipels geroep. Jesus het die revolusionêre karakter van God se koninkryk, wat in die wêreld met sy bekende norme ingebreek het, gedemonstreer deur na melaatses uit te reik én selfs aan hulle te raak, deur in die openbaar met vroue te gesels, deur kinders van heidene gesond te maak, prostitute toe te laat om Hom aan te raak, en deur saam met erkende swendelaars te eet.

Die geloofsgemeenskap wat Hy gevorm het, het hierdie revolusionêre wyse van inkarnerende getuienis voortgesit, alhoewel die kerk dikwels met die uitdagings wat dit meegebring het, moes worstel. Die gemeente in Jerusalem moes byvoorbeeld oortuig word dat Samaritane werklik volgelinge van Jesus kon word. Filippus moes gelei word om 'n Etiopiese hofamptenaar (ontmande), iemand wat nooit toegelaat sou word om in die tempelgemeenskap te aanbid nie, te evangeliseer. Die Nuwe Testamentiese kerk moes ook worstel met die vraag of die heidene kwalifiseer vir die Christelike geloofsgemeenskap. Van vroeg af moes die kerk in die wêreld dien as voorbeeld van 'n gemeenskap waar daar nie 'nou meer Jood of Griek, nie meer slaaf of vryman, nie meer man of vrou is nie, want julle is almal één in Christus Jesus!' (Gal 3:28). Wat inkarnerend gedemonstreer is in die bediening vanJesusen dievroeëkerk, is reeds gegeein diesendingmandaat van Handelinge 1:8 en die Groot Opdrag van Matteus 28:19.

Die missionale beweging in die laaste eeue is gemobiliseer deur 'n herontwaakte erkenning van die universele skopus van die evangelie:

We have realized that the 'world' in the New Testament cannot be restricted to Europe and its legacy, nor limited to a particular race, class, or ethnicity. In the life, death, and resurrection of Jesus, God has demonstrated his love for all the world (John 3:16). The incarnational reality is now te be demonstrated by the church's witness. (Guder 1999:49)

Die gevolg van hierdie herontwaakte visie van die evangelie vir die hele wêreld was dat die Christelike getuienis na feitlik elke kultuur op aarde uitgebrei het. Tans is die Christelike kerk in die ware sin van die woord, 'n wêreldkerk.

By terugskoue blyk dit egter dat baie van die sendingwerk nie werklik inkarnerend was nie. In baie gevalle is die gestuurdes se eie opvattings en dogma oor wat gehoorsaamheid aan die evangelie beteken (wat dikwels van denominasie tot denominasie verskil), op diegene na wie toe God hulle gestuur het, afgedruk.

Wat in die geval van die inkarnasie van Jesus (sy aardse lewe en bediening) gesien kan word, is 'n opmerklike en bevrydende kulturele vryheid. 'Jesus initiates his mission in such a way that it will be possiple to carry this message to all nations' (Guder 1999:50). Hy het sy dissipels so onderrig dat hulle in staat was om die evangelie in die verskillende kulture in eiesoortige, en toepaslike maniere te vertaal. Dit is die noodwendige uitvloeisel van die opdrag: 'Maak dissipels van alle nasies!' (vgl. Matt 28:19-20). Dit beteken dat dit nie vir 'n heiden-bekeerling nodig sou wees om eers 'n praktiserende Jood te word om Jesus te kan volg nie. Die Woord sal aanhou om vlees te word in al die diverse maniere waarop die mensdom gestalte kry in eiesoortige kulture. Die Groot Verhaal sal vertel word in elke taal, soos wat dit op Pinksterdag gebeur het. Die inkarnerende karakter van die kerk se sending beteken dat die uitbreidende kerk in alle opsigte multikultureel, in die omvattendste sin van die woord, sal wees. Die kerk se eenheid is gesentreer in Jesus Christus, maar dit is 'n eenheid wat nooit gedefinieer mag word as 'n organisatoriese of kulturele eenvormigheid nie.

So 'n verstaan van die multikulturele karakter van inkarnerende sending is wat missioloë beskryf as kontekstualisering (Van Gelder 2007:12 verv.). Kontekstualisering verwys na die verskillende prosesse waardeur 'n lokale geloofsgemeenskap die evangelie met die plaaslike konteks integreer. Die teks en konteks moet vervleg in één God-bedoelde werklikheid, naamlik Christelike lewe. Die terme kontekstualisering en inkarnering word deur sommige missioloë as sinonieme gebruik (vgl. Guder 1999:51).

Die sinonieme gebruik van die terme, kontekstualisering en inkarnering, is belangrik. Dit beklemtoon die feit dat God se liefde op verstaanbare maniere na ons toe gekom het en onder ons kom woon het. Die Woord het mens geword sodat mense die Woord kon ontmoet en op Hom kon reageer. Jesus het die boodskap van God se koninkryk op so 'n wyse vertaal dat ' $n$ belastinggaarder dit kon begryp, en ook ' $n$ prostituut, 'n melaatse,'nSamaritaan,'n geleerde Fariseër en ongeletterde vissermanne. Dit was vir Paulus moontlik om 'n Jood vir die Jode en 'n Griek vir die Grieke, ter wille van die evangelie te word. Volgens Handelinge het die geloofsgemeenskap in Jerusalem geleer dat daar 'n geloofsgemeenskap in Samaria kan wees, en dat daardie geloofsgemeenskap ook eg Christelik kan wees, terwyl hulle duidelik te onderskei is van die Christelike geloofsgemeenskap in die Joodse konteks. So het die apostels, veral Paulus, die evangelie in die Hellenistiese kulture vertaal en sodoende gewys dat God se liefde in 
Christus in elke kultuur geïnkarneer kan word. Dit was 'n moeilike les om te leer vir die geloofsgemeenskap van Jerusalem. 'n Vergadering was nodig om die spanning te verlig wat hierdie geïnkarneerde vertaling van die evangelie ontketen het.

Dit wat die Vroeë Kerk geleer en bevestig het, is van wesenlike belang vir die hedendaagse teologie van inkarnerende sending. Dit werk met die fundamentele vertrekpunt dat inkarnerende getuienis moontlik is op grond van die vertaalbaarheid van die evangelie in elke denkbare ruimte van menslike bestaan. Kultuur moet wyer verstaan word as slegs beperk tot ' $n$ bepaalde taal, gebruike, geografie en instituut. Daar moet steeds rekening gehou word met die feit dat daar diverse kulturele groeperinge is wat, al deel hulle dieselfde taal, grondgebied, en al lyk hulle uiterlik dieselfde, in baie opsigte totaal verskillend is. Die 'plausiblity structure' (vgl. Guder 1999:52) van 'n tradisionele Afrikaanse, Amerikaanse, Engelse of watter kultuur ook al, met 'n relatief identifiseerbare konsensus oor geloof, waardes, gesinstrukture en moraliteit, bestaan in baie gevalle nie meer nie. Die wêreld van vandag vertoon 'n pluralisme van 'plausible structures', waarin min of meer dieselfde taal gepraat word, terwyl daar nie werklik daarin geslaag word om van groep tot groep te kommunikeer nie. Die begrip 'kultuur' word hier gebruik in die wydste moontlike sin: belangegroepe, ontspannings voorkeure, ouderdom, puberteit, jeug, stedelik, voorstedelik, plattelands, sosiale stand, seksualiteit en so meer.

Indien die NHKA ernstig is om missionaal kerk te wees, sal die NHKA, die unieke wyse waarop die Kerk se missionale roeping geïnkarneer word, krities moet evalueer. Elke gemeente van die NHKA sal moet vra na die wyse hoe hulle getuienis, die evangelie beliggaam vir die kulturele groeperinge anders as hulle eie. Elke gemeente moet vra of hulle spesifieke vertaling van die evangelie nog verstaanbaar is vir die verskillende kulturele groeperinge wat deel uitmaak van die gemeente se konteks. Die kritiese vraag aan elke gemeente is of hulle nie steeds van hierdie kultureel diverse groeperinge verwag om by 'ons aan te pas', in ons gevestigde vorme van Christenwees, voordat hulle volgens ons 'waardig' genoeg is om die evangelie in die eerste plek te mag hoor nie.

Om inkarnerende getuienis te beoefen beteken om die verskillende kulture, wat deel van ons kontekste uitmaak, te ken en te verstaan; dit beteken om te leer wát hulle en hóé hulle dink, hoe dit voel om deel van hulle wêreld te wees, en hoe om op hulle terme te kommunikeer. Die Christen missionale gemeenskap moet dus leer om kultureel 'meertalig' te wees (vgl. Guder 1999:54). Sodanige meertaligheid is nie bloot ' $n$ kwessie van verbale taal nie.

Die fundamentele diversiteit van God se wêreld bly 'n reuse uitdaging vir alle Christene. Dit was die uitdaging aan die Joodse Christene van die eerste eeu in Jerusalem, en dit is vandag nie anders nie. Op subtiele maniere dring dinge soos rassisme, nasionalisme, homofobie en so meer hulleself telkens weer aan geloofsgemeenskappe op, met die gevolg dat daar reuse reduksionismes plaasvind in terme van die uitdra van die evangelie. Wanneer Jesus ons as sy getuies vorm, om met ander woorde sy boodskap te inkarneer, dwing $\mathrm{Hy}$ ons tegelykertyd ook om ons eie kulturele bekrompenheid en trots onder die loep te neem.

Wanneer ons dan vra wie die melaatses en die Samaritane van ons tyd is, en ons waag 'n eerlike antwoord, ontdek ons baie keer ons eie dringende behoefte aan berou en bekering. Na so ' $n$ bekering is dit moontlik dat 'n geloofsgemeenskap ontluik wat Christus se liefde getrouer inkarneer en wat in staat is om ander met Christus se liefde te nooi om deel te word van sy liggaam.

\section{Konklusie}

Inkarnerende getuienis kry gestalte in 'n geloofsgemeenskap se voortdurende bekering as die kragtige werk van God se Gees in en deur ons (Peterson 2013:77 verv.). Daar is niks wat ons van ons kant af kan doen om onsself in getuies met integriteit te verander nie. Die helende werk van God bly God se werk en die geloofsgemeenskap bly die ontvangers. Inkarnerende getuienis is gewortel in die vertroue dat God se verlossingswerk wat in Christus afgehandel is, ons vooruitgaan, ons ondersteun en konfronteer. Hier word nie gepraat van 'wat ons moet doen om gered te word' nie. Dit gaan hier oor wat dit beteken om van die verlossing te getuig wat ons reeds en steeds van Christus en in Christus ontvang. 'Our knowledge or certainty of salvation is ultimately not the issue for the missional church. That salvation is what makes us into a missional church to begin with' (Guder 1999:58).

Dit is in hierdie voortgaande bekeringsproses (hervorming) waarin die NHKA se getuienis die grondigste geïnkarneer kan word. Dit is in die NHKA se eie heling en vergifnis waar die goeie nuus gesien sal kan word, of nie. Dit is per slot van sake God self wat in die NHKA werk en wat sy werk sal volvoer (Fil 1:6). God se getrouheid bestaan uit die voortdurende gee van sy Gees en in die voortgaande heling van ons lewens. Ons word bemagtig om te antwoord op die 'goeie nuus' soos wat aan ons verkondig word. Daardie antwoord is die eerste bewys van die teenwoordigheid van Christus in ons lewenswerklikheid. Dit is soos wat Christene self geëvangeliseer word dat hulle egte evangeliste word.

Die geloofsgemeenskappe kan slegs leer hoe om inkarnerende getuies te wees en hoe om inkarnerend te getuig wanneer hulle aandag gee aan die Nuwe Testamentiese imperatiewe. Dit is uiteraard volledig moontlik en tegelyk menslik ook moeilik om hierdie imperatiewe te gehoorsaam. Maar God se Gees is spesifiek hiervoor gegee, sodat in en deur die bemagtiging van die Gees, geloofsgemeenskappe in staat sal wees om tot bekering te kom en om deur Christus gevorm te word om in sy voetspore te loop. Hierdie vorming vind plaas wanneer geloofsgemeenskappe leer hoe om Christus te volg. Gedissiplineerde omgang met die Skrif is die enigste manier hoe dit kan gebeur. Die uitdaging waarvoor die NHKA staan 
is om die NHKA as empiriese subjek (hoe die Kerk prakties gestalte kry in die lewe en werk van plaaslike gemeentes) en die gedefinieerde subjek (hoe die Kerk teologies beskryf is) nader aan mekaar te bring. In hierdie proses sal kritiese vrae gevra moet word. Dit sluit vrae in soos: Met die oog waarop word daar gepreek? Met die oog waarop word pastoraat beoefen? Met die oog waarop word Bybelstudies in gemeentes aangebied? Met die oog waarop word kategese gedoen? Met die oog waarop word diakonaat beoefen? Met die oog waarop word teologiese opleiding gedoen? Indien dit nie met die oog daarop is om van Jesus se dissipels, Jesus se gestuurde getuies te maak nie - so glo ek - is daar 'n ernstige noodsaak aan bekering teenwoordig!

\section{Erkenning \\ Mededingende belange}

Die outeur verklaar hiermee dat hy geen finansiële of persoonlike verbintenis het met enige party wat hom nadelig of voordelig kon beïnvloed het in die skryf van hierdie artikel.

\section{Literatuurverwysings}

Armour, M.C. \& Browning, D., 2006, Systems sensitive leadership, College Press Publishing Company, Joplin, $\mathrm{MO}$.

Bonhoeffer, D., 1959, The cost of discipleship, SCM Press, London.

Borg, M.J. \& Scorer, T., 2006, Living the heart of Christianity: A guide to putting you faith into action, Harper Collins Publishers, New York, NY.

Bosch, D.J., 1993, Transforming mission: Paradigm shifts in theology of mission, Orbis Books, Maryknoll, New York, NY.

Buitendag, J., 2008, 'Ecclesia reformata semper reformanda - die ongemaklike eis', HTS Teologiese Studies/Theological Studies 64(1), 73-109. http://dx.doi. org/10.4102/hts.v64i1.7

Burger, C., 1991, Die dinamika van 'n Christelike geloofsgemeenskap, Lux Verbi, Kaapstad.

Burger, C., 1992, 'Die veranderende samelewingssituasie in Suid-Afrika', in H.J. Hendriks (red.), Gemeentes vertel, bl. 11-22, Lux Verbi, Kaapstad.

Burger, C., 1997, Familie van God, Lux Verbi, Kaapstad.

Callahan, K.L., 1990, Effective church leadership: Building on the twelve keys, HarperSanFrancisco, New York, NY

Deist, F., 1989, 'Die kerk. 'n Vereenigende of verdelende faktor in die ontwikkeling van Suid-Afrika?', HTS Teologiese Studies/Theological Studies 45(4), 894-915. http:// dx.doi.org/10.4102/hts.v45i4.2339

Dreyer, T.F.J., 2003, 'Statistieke vertel 'n storie -'n visie vir die Hervormde Kerk op pad na 2010', HTS Teologiese Studies/Theological Studies 59(4), 1045-1062. http:// dx.doi.org/10.4102/hts.v59i4.685

Dreyer, W.A., 2011, 'Histories-vergelykende ekklesiologie - oppad na 'n omvattende praktiese ekklesiologie', HTS Teologiese Studies/Theological Studies 67(3), Art. \#1083, 8 pages. http://dx.doi.org/10.4102/hts.v67i3.1083

Dulles, A., 1987, Models of the Church, Image Books, Garden City, NY.

Gaum, F., 2011, Fluit-fluit die kerk is uit, Bybelmedia, Tygerberg.

Guder, D.L.,1999, The incarnation and the church's witness, Trinity Press International, Harriburg, PA.

Hendriks, H.J., 1992, Strategiese beplanning in gemeentes, Hugenote, Wellington.

Hirsch, A., 2006, The forgotten ways: Reactivating the missional church, Brazos Press, Grand Rapids, MI.

Hirsch, A. \& Altclass, D., 2009, The forgotten ways handbook, BrazosPress, Grand Rapids, MI.

Hirsch, A. \& Catchim, T., 2012, The permanent revolution, Jossey-Bass, San Franciscom CA.

Joubert, S., 2009, Jesus ' $n$ radikale sprong, Christelike Uitgewersmaatskappy, Vereeniging.
Kirk, J.A., 2000, What is mission?: Theological explorations, Fortress Press, Minneapolis, MN.

Koekemoer, J.H., 1987, 'Die volksvoorstelling in die Kerkwet van die Nederduitsch Hervormde Kerk van Afrika', HTS Teologiese Studies/Theological Studies 43(1/2), $13-25$.

Koekemoer, J.H., 1990, 'Die na-binne of introverte gerigtheid van "Kerk en wêreld 2000"', HTS Teologiese Studies/Theological Studies 46(4), 708-715. http://dx.doi. org/10.4102/hts.v46i4.2365

Koekemoer, J.H., 1995, 'Die kerk as gebeure: 'n Dogmatiese perspektief', HTS Teologiese Studies/Theological Studies 51(3), 595-603. http://dx.doi.org/10.4102/hts. v51i3.1416

König, A., 1998, Vernuwe of verdwyn, hoe oop is die NG Kerk vir verskillende vorme van aanbidding?, Lux Verbi, Kaapstad.

Malphurs, A. 1993, Pouring new wine into old wineskins: How to change a church without distroying it, Baker Books, Grand Rapids, MI.

Marias, F., 2007, God praat, leef luisteryk, Bybelkor, Wellington.

Nederduitsch Hervormde Kerk van Afrika (NHKA), 2004, Agenda vir die 67ste Algemene Kerkvergadering van die Nederduitsch Hervormde Kerk van Afrika, Kerkargief, Pretoria.

Nederduitsch Hervormde Kerk van Afrika (NHKA), 2007, Agenda vir die 68ste Algemene Kerkvergadering van die Nederduitsch Hervormde Kerk van Afrika, Kerkargief, Pretoria.

Nederduitsch Hervormde Kerk van Afrika (NHKA), 2010a, Agenda vir die 69ste Algemene Kerkvergadering van die Nederduitsch Hervormde Kerk van Afrika, Kerkargief, Pretoria.

Nederduitsch Hervormde Kerk van Afrika (NHKA), 2010b, Besluitebundel 69ste Algemene Kerkvergadering, Kerkargief, Pretoria.

Nederduitsch Hervormde Kerk van Afrika (NHKA), 2013, Kerkorde van die Nederduitsch Hervormde Kerk van Afrika, 69ste Algemene Kerkvergadering, Kerkargief, Pretoria.

Nel, M., 1994, Gemeentebou, Orion Uitgewers, Halfway House.

Oberholzer, J.P., 1985, 'Die taak van die kerk teenoor die owerheid', HTS Teologiese Studies/Theological Studies 41(1), 14-28.

Ott, H., 1981, Die Antwort des Glaubens, Kreuz Verlag, Stuttgart.

Peters, A., 2000, Tot Uw dienst: Een diaconaal bijdrage aan gemeenteopbouw, Boekencentrum, Zoetemeer.

Peterson, C.M., 2013, Who is the Church? An ecclesiology for the twenty-first century, Fortress Press, Minneapolis, MN

Robinson, A., 2003, Transforming congregational culture, William B. Eerdmans, Grand Rapids, MI.

Robinson, A., 2008, Changing the conversation: A third way for congregations, William B. Eerdmans, Grand Rapids, MI.

Sjogren, S., 1993, Conspiracy of kindness, Vin Books, Cincinatti, OH.

Snyder, H.A., 1991, Models of the kingdom, Abingdon, Nashville, TN.

Tyra, G., 2013, A missional orthodoxy: Theology and ministry in a post-Christian context, IVP Academic, Downers Grovem IL.

Van Aarde, A.G., 1995, 'Kerk en teologie op pad na die derde millennium: Gedagtes oor die kontekstualisering van die dialektiese teologie in 'n plurale samelewing', HTS Teologiese Studies/Theological Studies 51(1), 39-64.

Van der Merwe, J.C., 2009, Fakulteitsopening, Universiteit van Pretoria, Pretoria, Februarie.

Van der Merwe, J.C., 2011, 'Missionale gemeentes in die Nederduitsch Hervormde Kerk van Afrika - Teologies verantwoord', HTS Teologiese Studies/Theological Studies 67(3), Art. \#1094, 9 pages. http://dx.doi.org/10.4102.hts.v67i3.1094

Van der Merwe, J.C., 2014, 'n Narratief vir kerk-wees vandag', HTS Teologiese Studies/ Theological Studies 70(1), Art. \#2699, 13 pages. http://dx.doi.org/10.4102/hts. v70i1.2699

Van der Merwe, J.C. \& Beukes, P., 1997, 'Die missionere geregtigheid van die kerk', HTS Teologiese Studies/Theological Studies 53(3), 705-721. http://dx.doi.org/10.4102/ hts.v53i3.1690

Van der Westhuizen, H.G., 1992, 'Toenemend kerk', HTS Teologiese Studies/Theological Studies 48(3/4), 977-993. http://dx.doi.org/10.4102/hts.v48i3/4.2464

Van Gelder, C., 2007, 'Missiology and the missional church in context', in C. van Gelder (ed.), The missional church in context: Helping congregations develop contextual ministry, pp. 12-43, Wim B. Eerdmans, Grand Rapids, MI.

Van Wyk, D.J.C., 1996, 'Die roeping van die Kerk in 'n veranderde Suid-Afrika', HTS Teologiese Studies/Theological Studies 52(1), 147-164.

Velthuyzen, G.C., 1988, 'Die wese van die kerk: 'n Teologiese antwoord op 'n filosofiese vraag', HTS Teologiese Studies/Theological Studies 44, 489-513.

Ward, P., 2002, Liquid church: A bold vision of how to be God's people in worship and mission - A flexible, fluid way of being church, Hendrickson Publishers, Peabody.

Watson, D., 1983, Discipleship, Hodder \& Stoughton, London.

Wright, C.J.H., 2006, The Mission of God: Unlocking the Bible's grand narrative, IVP Academic, Downers Grove, IL. 